\title{
Eocene planktonic foraminifera from the north Eastern Desert, Egypt: Biostratigraphic, paleoenvironmental and sequence stratigraphy implications
}

\author{
Yasser Salama, Mostafa Sayed, Shaban Saber, and Ibrahim Abd El-Gaied
}

\begin{abstract}
The Eocene succession at Beni Suef -El Zaafarana District in north Eastern Desert is rich in planktonic foraminiferal assemblages. The main objectives of this work are to use the planktonic foraminifera to recognize the biostratigraphy for the Middle-Upper Eocene succession in the study area. Seventy planktonic foraminiferal species belonging to 20 genera and seven families are identified from the Eocene El Fashn and Beni Suef formations. Three planktonic foraminiferal biozones are recognized. These are from older to younger Morozovelloides crassatus Zone (late Middle Eocene) that is recorded from El Fashn Formation, Globigerinatheka semiinvoluta Zone (latest Middle Eocene -Late Eocene) and Globigerinatheka index Zone (Late Eocene age) that are recorded from the Beni Suef Formation while the Maadi Formation is found barren in planktonic foraminifera. These zones are correlated with those from nearby areas in Egypt and the Mediterranean regions. The Middle/Upper Eocene (Bartonian/Priabonian) boundary is discussed here in detail. The percentage of the planktonic foraminifera in the total foraminiferal content $(P \%)$ points to a change in water depth. There was a significant decrease in the planktonic/benthic foraminiferal ratio from the late Middle Eocene El Fashn Formation to the Late Eocene Maadi Formation at Beni Suef -El Zaafarana District. This ratio change supports a shallowing upward in paleodepth. Based on the lithology, planktonic/benthic ratio and the obtained water depth, the studied Eocene succession could be subdivided into four depositional sequences. These sequences agree with the global eustatic sea-level and the depositional sequences in nearby areas.
\end{abstract}

Yasser Salama. Geology Department, Faculty of Science, Beni-Suef University, 65211, Egypt. Yasser.salama@science.bsu.edu.eg (Corresponding author) Mostafa Sayed. Geology Department, Faculty of Science, Beni-Suef University, 65211, Egypt. mostafa.sayed92@science.bsu.edu.eg Shaban Saber. Geology Department, Faculty of Science, Beni-Suef University, 65211, Egypt. shaban.saber@science.bsu.edu.eg Ibrahim Abd El-Gaied. Geology Department, Faculty of Science, Beni-Suef University, 65211, Egypt. ibrahim.mohamed@science.bsu.edu.eg

Salama, Yasser, Sayed, Mostafa, Saber, Shaban, and Abd El-Gaied, Ibrahim. 2021. Eocene planktonic foraminifera from the north Eastern Desert, Egypt: Biostratigraphic, paleoenvironmental and sequence stratigraphy implications. Palaeontologia Electronica, 24(1):a11. https://doi.org/10.26879/1088

palaeo-electronica.org/content/2021/3323-eocene-planktonic-foraminifera

Copyright: March 2021 Palaeontological Association.

This is an open access article distributed under the terms of Attribution-NonCommercial-ShareAlike 4.0 International (CC BY-NC-SA 4.0), which permits users to copy and redistribute the material in any medium or format, provided it is not used for commercial purposes and the original author and source are credited, with indications if any changes are made.

creativecommons.org/licenses/by-nc-sa/4.0/ 


\section{INTRODUCTION}

The Eocene Epoch witnessed the development of a carbonate platform covering a huge area of Egypt (Said, 1962; Saber and Salama, 2017; Abd El-Gaied et al., 2019). The foraminiferal contents of the Eocene platform were the target for many previous studies in the Nile Valley and the north Eastern Desert (Bassiouni et al., 1974, 1975; Kenawy et al., 1977; Haggag, 1986, 1989 b; Haggag and Anan, 1987; Haggag and Luterbacher, 1991; Haggag and Bolli, 1995, 1996; Hussein, 1994; Obaidalla and El-Ayyat, 2001; El-Dawy and Dakrory, 2005; Strougo et al., 2013; El Ayyat and Obaidalla, 2016; Abdel-Fattah, 2018). The planktonic foraminifera are a basic group of fossils in the biostratigraphy and depositional environment interpretation. The wide geographical distribution and high species diversity of the planktonic foraminiferal group enabled us to use this group in correlation with the Eocene rocks (BouDagher-Fadel, 2012). The occurrence of planktonic and benthic foraminifera is considered a valuable tool in the determination of the paleobathymetry and paleoecological changes. Their abundance and diversity are related to changes in oceanographic parameters such as temperature, salinity, organic flux, and sea level fluctuations (Leckie et al., 1998; Ernst and Van der Zwaan, 2004; Darabi et al., 2018). Planktonic foraminifera are rare or nearly absent in near shore environments and increase in abundance with increasing depth (van Hinsbergen et al., 2005). The planktonic/benthic foraminifera ratio $(P / B)$ reflects changes in the environmental settings from inner to outer neritic environments (Murray, 2006; Pippèrr and Reichenbacher, 2010; Pippèrr, 2011).

The foraminiferal contents and biostratigraphy of the Middle-Upper Eocene successions are previously studied in the north Eastern Desert, at wadi Bayad El-Arab and Gebel Homret Shaibon (Abd El-Gaied and Abd El-Aziz, 2005; Aly et al. 2011); they identified only two planktonic foraminifera zones including Truncorotaloides (Acarinina) rohri and Turborotalia (ampliapertura) pseudoampliapertura zones, and two benthic foraminifera zones including Palmula ansaryi and Bulimina jacksonensis zones. However, this biostratigraphy result was poorly discussed and the studied sections are suit- able to complement the biostratigraphic record of the Middle-Upper Eocene successions in the north Eastern Desert, particularly at the Beni Suef area.

The study area has not been subjected to sufficient studies because of the difficulty in reaching it, but with new asphaltic roads, researchers can easily access the Eocene successions along Beni Suef -El Zaafarana. Recently, Abd El-Gaied et al. (2019) studied in detail the benthic foraminiferal assemblages and paleoenvironment of the MiddleLate Eocene succession in this area. However, the micropaleontological studies of the Eocene sequence by means of planktonic foraminifera in the study area in the north Eastern Desert were not the subject of sufficient previous works. Therefore, the foremost purpose of this study is to develop the biostratigraphic frame of the middle-upper Eocene deposits in the east Beni Suef area, north Eastern Desert.

In this study we report stratigraphical and micropaleontological results for the Middle-Upper Eocene succession by using planktonic foraminifera data. The goals of this work are also to study the biostratigraphic zonation and to determine the paleobathemetry of the studied sequences. Although the Eocene sequence stratigraphy in Eocene successions of north Eastern Desert was subject to few studies, a sequence stratigraphic classification for the Middle-Upper Eocene succession in the studied area is attempted also here for the first time. Although the Eocene sequence stratigraphy of north Eastern Desert was previously studied by a few number of authors (Tawfik et al., 2016; Saber and Salama, 2017; Hussein, 2019), the present study highlight the planktonic foraminifera ratio and sea level changes from the perspective of sequence stratigraphy.

\section{LITHOSTRATIGRAPHY}

Three stratigraphic sections in the study area were analysed for planktonic foraminifera. These sections are located along the eastern side of the Nile River, the first section (A) is located at about $15 \mathrm{~km}$ east of Beni Suef city between latitude $28^{\circ}$ $59^{\prime} \mathrm{N}$ and longitude $31^{\circ} 11^{\prime} \mathrm{E}$; the second $(\mathrm{B})$ is located at about $20 \mathrm{~km}$ east of Beni Suef city between latitude $28^{\circ} 57^{\prime} \mathrm{N}$ and longitude $31^{\circ} 13^{\prime} \mathrm{E}$, while the third section (C) is located at about 135 
$\mathrm{km}$ west of El Zaafarana between latitude $28^{\circ} 58^{\prime} \mathrm{N}$ and longitude $31^{\circ} 22^{\prime} \mathrm{E}$ (Figure 1). The studied succession was differentiated into three rock units, arranged from base to top: the El Fashn Formation (late Middle Eocene), the Beni Suef Formation (late Middle Eocene-Late Eocene), and the Maadi Formation (Late Eocene) (Figure 2). The El Fashn Formation was first described by Bishay (1966) at Wadi El Sheikh southeast of El Fashn City as a sequence of sandy and chalky limestone and sandy shales of $88 \mathrm{~m}$ thick. In the study area, the upper part of this formation is exposed and unconformably overlain by the Beni Suef Formation. It attains a thickness of about $35 \mathrm{~m}$ consisting of grayish white, hard and burrowed massive limestone, yellowish white marly limestone, and egg yellow marl intercalations (Figure 3). This rock unit is highly fossiliferous with benthic and planktonic foraminifera, which are highly abundant in the marl beds and less abundant in the limestone and marly limestone beds. The planktonic foraminiferal assemblages suggest a late Middle Eocene (Bartonian) age for this rock unit.
The Beni Suef Formation was first described by Bishay (1966) to describe the succession exposed at Gebel Homret Shaibon overlying the El Fashn Formation and underlying the Maadi Formation. Mansour et al. (1982) subdivided this formation into the Qurn Member at the base and the Tarbul Member at the top. In the studied area, the Beni Suef Formation exposed at sections B and C and subdivided into two members. The lower Qurn Member which exposes at the lower part of section $\mathrm{B}$, where it measures $54 \mathrm{~m}$ and is composed mainly of grayish yellow gypsiferous shale, silty shale, and light green marl. The upper Tarbul Member was recorded at the upper part of section $B$ and measured $24 \mathrm{~m}$ (Figure 4). It composes of yellowish gray hard marly limestone, greenish yellow shale, and yellowish white marl with a thin bed of hard egg yellow thalassinoid limestone capped by chalky and dolomitic limestone. This member includes the majority of section $\mathrm{C}$, with a thickness of about $63 \mathrm{~m}$. The basal part of the Tarbul Member (8 $\mathrm{m}$ thick) in section $\mathrm{C}$ consists of fossiliferous egg yellow marls and yellowish white marly limestone. The middle part is about $25 \mathrm{~m}$ thick and consists of
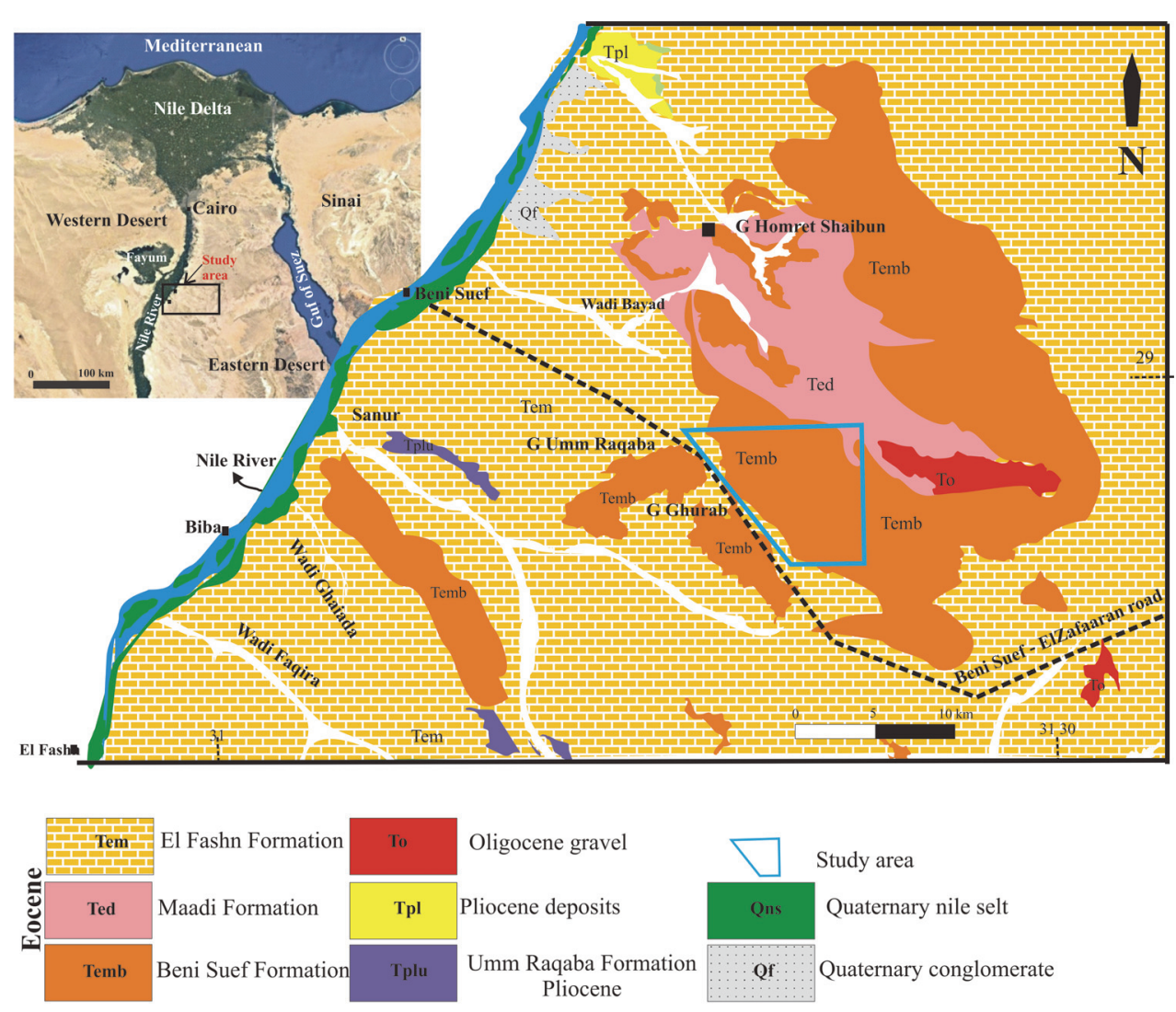

FIGURE 1. Location and geological maps of the studied sections (Modified after Saber and Salama 2017). 
(C)

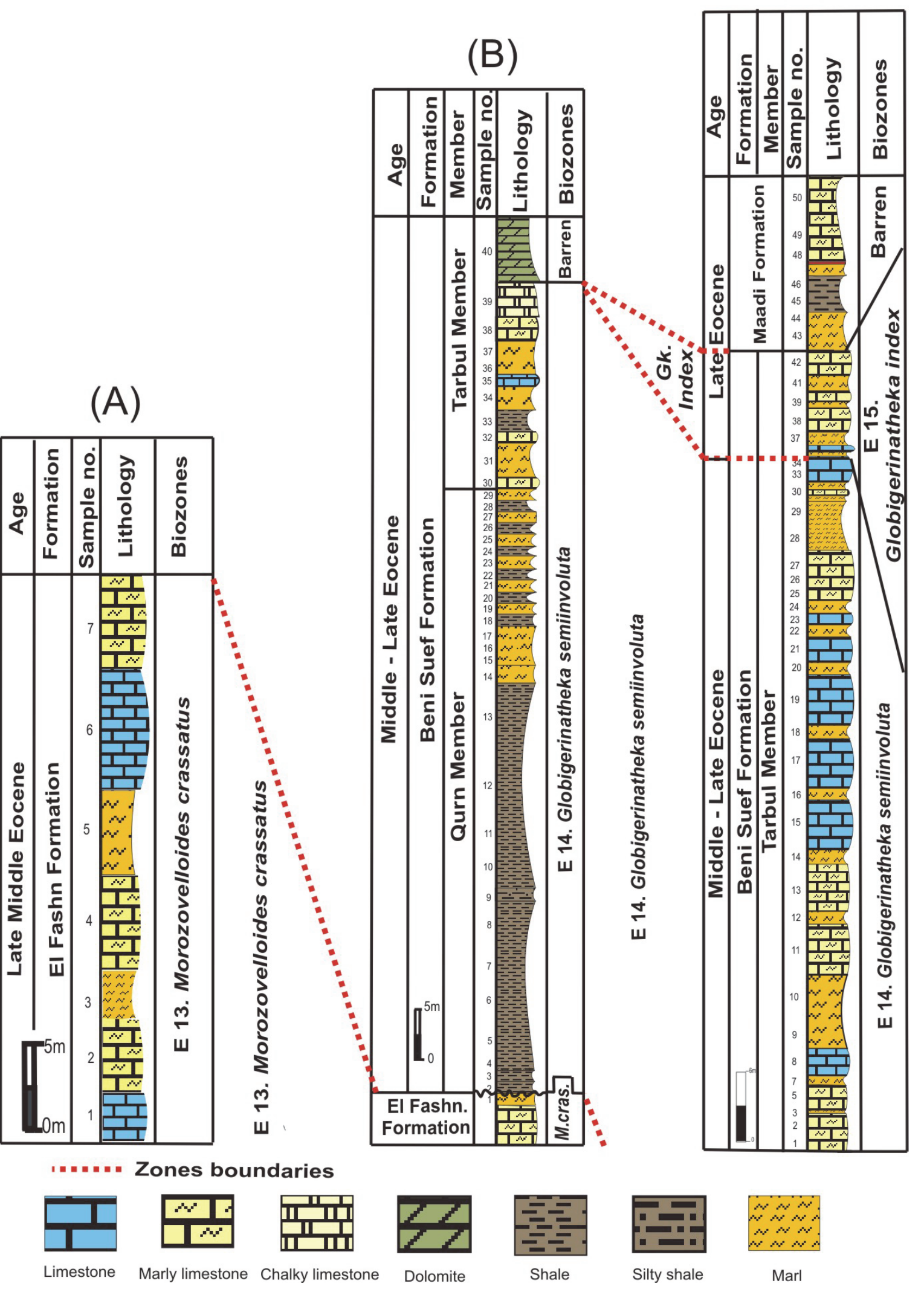

FIGURE 2. Lithologic and biostratigraphic units of the studied sections (A, B, C). 


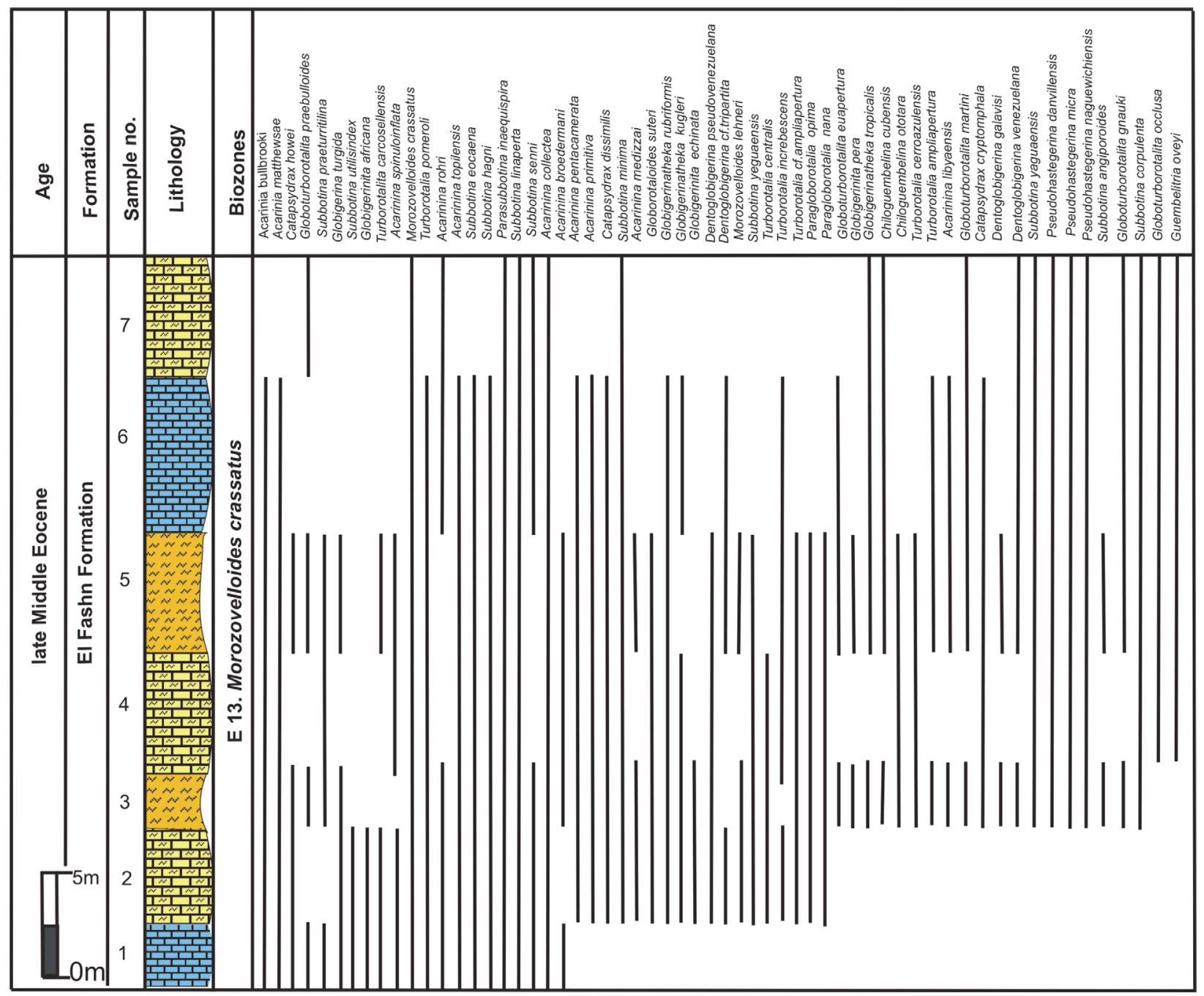

FIGURE 3. Range chart of the identified planktonic species in section A.

egg yellow to yellowish white marl. The upper part of this member is $30 \mathrm{~m}$ thick and is composed of various colors of marl and fossiliferous limestone. The abundance and diversity of planktonic foraminiferal species in the lower part of the Beni Suef Formation are greater than those in the middle and upper parts. Based on the occurrence of both planktonic and benthic foraminifera, the Beni Suef Formation in the present work is assigned to a late Middle to Late Eocene age.

The Maadi Formation was first described by Said $(1962,1971)$ as part of the upper Mokattam of Zittel (1883). Its type locality is at east of the Maadi district with a thickness of about $70 \mathrm{~m}$, composed of variegated and gypsiferous shale overlain by limestone, calcareous sandstone, and dolostone. In the study area, the lower part of the Maadi Formation is exposed in section $\mathrm{C}$, with a thickness of about $14 \mathrm{~m}$ of shale and egg yellow sandy marls
(Figure 5). The marl beds were highly fossiliferous containing large echinoids, gastropods, pelecypods (Carolia placunoides), Nummulites spp., and abundant corals. No planktonic foraminiferal species are found in this formation but it is enriched in large and small benthic foraminifera.

\section{METHODOLOGY}

In order to achieve the aim of the present study, 97 rock samples were collected from the measured three sections at $50 \mathrm{~cm}$ to $2 \mathrm{~m}$ intervals. At least $250 \mathrm{gm}$ was taken from each sample to extract the microfaunal contents. The samples were soaked in hydrogen peroxide solution. The samples were washed under running water and sieved using a $63 \mu \mathrm{m}$ sieve. The residue was dried and separated into several fractions to facilitate the picking of different microfossils using a binocular 


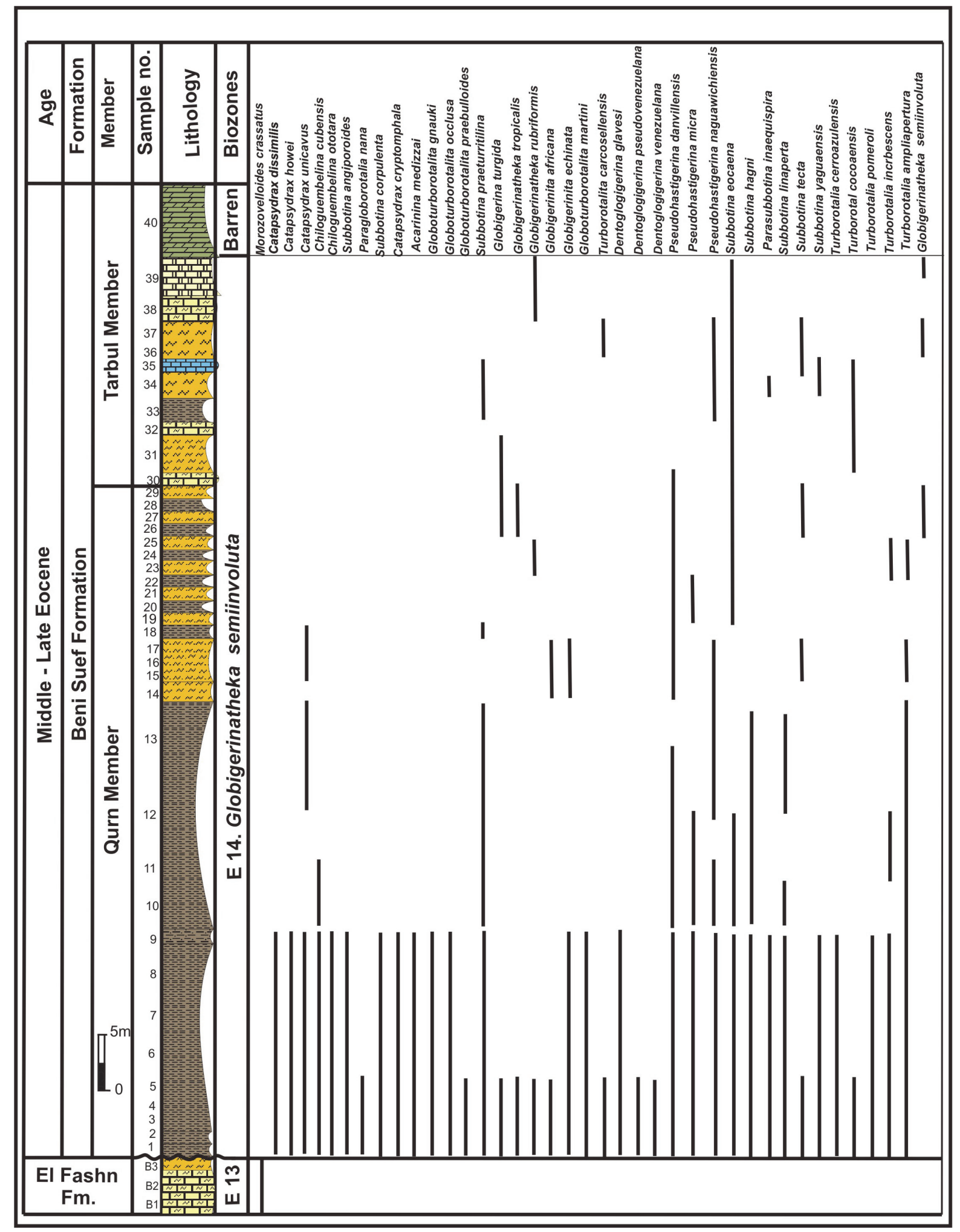

FIGURE 4. Range chart of the identified planktonic foraminifera at section B. 


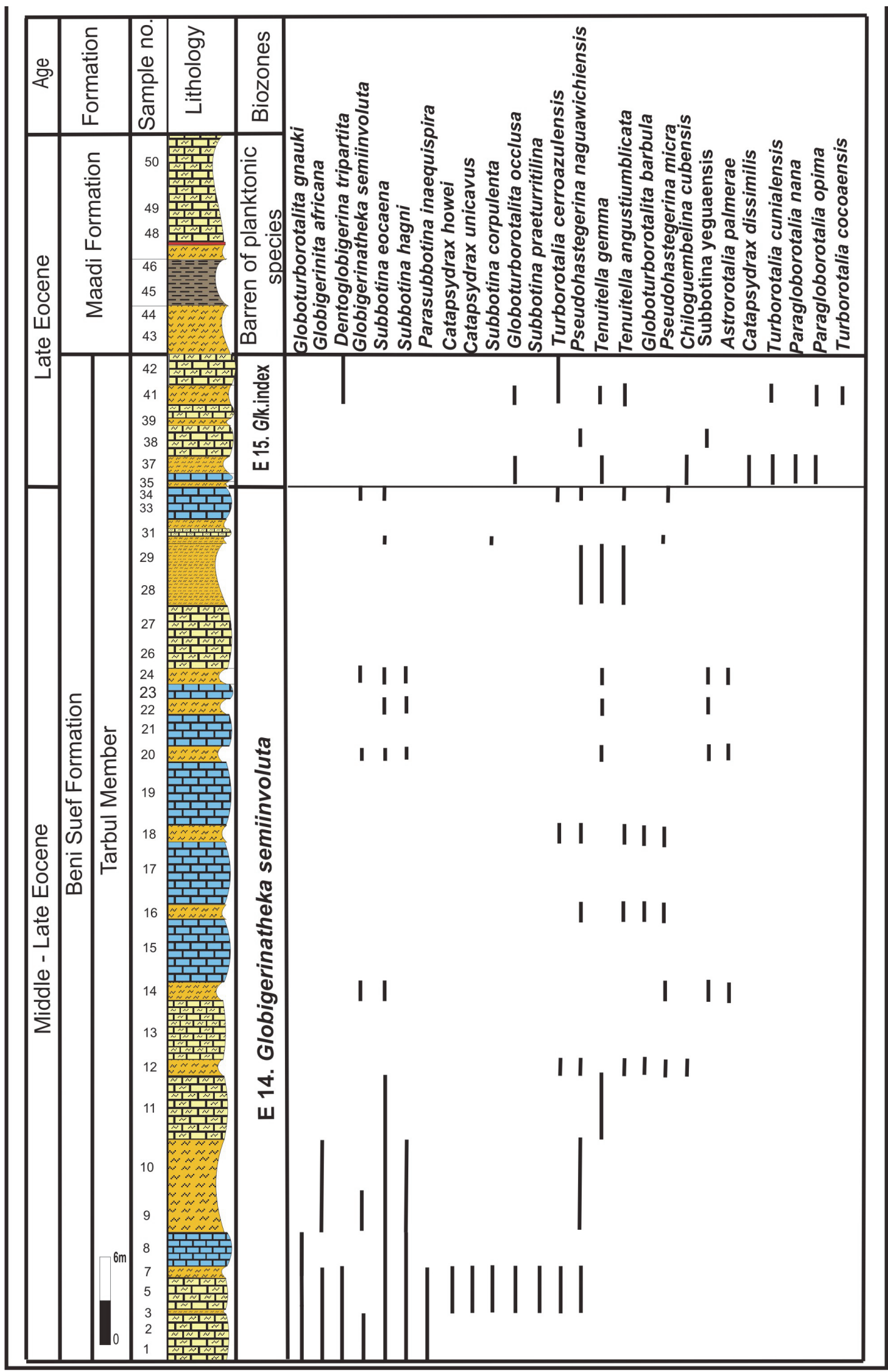

FIGURE 5. Range chart of the identified planktonic species in section C. 
microscope. The picked foraminiferal tests were identified to species-level and photographed by SEM (Scanning Electron Microscope, JSM 5400 LD at Assiut University). The planktonic and benthic foraminiferal species were counted in each sample to calculate the planktonic percentage in the total foraminiferal associations (P\%). This percentage could be estimated by applying the following formula: $P \%=100 *(P /(P+B-S)$. Where $P$ is the number of planktonic foraminiferal species, $B$ is the total number of benthic species and $S$ is the number of infaunal benthic species (Bulimina, Bolivina, Lagena, etc.). Paleodepth is obtained by using the equation by van der Zwaan et al (1990):

$$
\text { Depth }(m)=e 3.58718+\left(0.03534^{*} \mathrm{P} \%\right)
$$

Where $\mathrm{e}$ is the base of the natural logarithm $(\mathrm{e}=$ $2.718281825)$ and $\mathrm{P} \%$ is the planktonic percentage.

\section{SYSTEMATIC PALEONTOLOGY}

The planktonic foraminiferal investigation of the studied successions resulted in the identification of seventy planktonic species belonging to seven families and 20 genera. The taxonomy of Pearson et al. (2006) and Pearson and Wade (2015) are followed in this study. The age and stratigraphic distribution of the recorded species were highlighted (Figures 3, 4, 5). The identified species have been examined and photographed using a Scanning Electron Microscope (SEM) and illustrated in Figures 6, 7, and 8. The type specimens of this work were housed in the Geological Department, Faculty of Science, Beni-Suef University. The identified planktonic foraminifera species are summarized in Table 1.

\section{BIOSTRATIGRAPHY}

The stratigraphic distribution of the identified planktonic foraminiferal species allowed us to identify four planktonic foraminiferal zones for the upper Middle to Upper Eocene successions (Figures 2, 3, 4, 5). These zones were described and correlated with the international standard zones, and with those recorded in Egypt and the Tethyan province (Figure 9). The present zonation followed the most recent Cenozoic planktonic foraminifera scheme of Wade et al. (2011).

\section{E 13. Morozovelloides crassatus Zone}

Category. Highest-Occurrence Zone.

Definition. This zone was defined by Wade et al. (2011) as a highest-occurrence zone including the biostratigraphic interval between the highest occur- rence $(\mathrm{HO})$ of Orbulinoides beckmanni to the $\mathrm{HO}$ of Morozovelloides crassatus. In this work, the base of the present zone was not found because Orbulinoides beckmanni was absent and no other alternative species were found.

Age. late Middle Eocene (Bartonian).

Assemblages. The most characteristic species are Acarinina rohri, A. topilensis, A. libyaensis, A. matthewsae, A. spinuloinflata, A. bullbrooki, $A$. primitiva, A. collactea, A. pentacamerata, Igorina broedermanni, Morozovelloides crassatus, M. lehneri, Subbotina minima, Subbotina senni, S. utilisindex, Globorotaloides suteri, Turborotalia cf. ampliapertura, Turborotalia centralis, Globigerinita pera, Globoturborotalita euapertura, Guembelitria oveyi, and Globigerinatheka kugleri.

The most important benthic species recorded in this zone include assemblages of the genera Palmula (P. ansaryi, P. cushmani, P. suturalis, $P$. toulmin), Lenticulina, Pararotalia (P.audouini, $P$. spinigera), Anomalinoides (A. fayoumensis), Lagena, Cibicidoides (C. pharaonis, C. proprius), Uvigerina $(U$. peregrine, $U$. isidroensis, $U$. capayana, U. rippensis), Eponides (E. ellisorae, E. lotus) and Planulina (P. cocoaensis).

Remarks. This zone is occured in sections $A$ and $B$ of the El Fashn Formation (Figure 3) and characterized by high abundance of spinose planktonic foraminifera (Acarinina). In the tropical and subtropical areas, which are characterized by open marine conditions, the upper boundary of this zone marked the Middle / Late Eocene boundary. This boundary is marked by the disappearance of almost all spinose planktonic species (e.g. Morozovelloides and the large Acarinina spp.) (Toumarkine and Luterbacher, 1985; Haggag, 1990; Haggag and Luterbacher, 1991; Berggren and Pearson., 2005 and Wade et al., 2011). Berggren et al. (1995) marked overlap interval between the $\mathrm{HO}$ of Acarinina rohri and the LO of Globigerinatheka semiinvoluta, and they considered Globigerinatheka semiinvoluta is slightly older than the HO of Acarinina rohri (Abd El-Shafy et al., 2007). On the other hand, Berggren and Miller (1988) and Berggren et al. (1985) marked the top of Truncorotaloides rohri-Morozovella spinulosa Zones (P14) at the simultaneous extinction of Morozovella spinulosa and LO of Globigerinatheka semiinvoluta. Berggren and Pearson (2005) and Wade et al. (2011) noticed that Morozovelloides crassatus is the senior synonym of Morozovelloides spinulosa, so they defined Morozovelloides crassatus Zone (E13) from the $\mathrm{HO}$ of Orbulinoides beckmanni to the $\mathrm{HO}$ of Morozovelloides crassatus. In this work, 

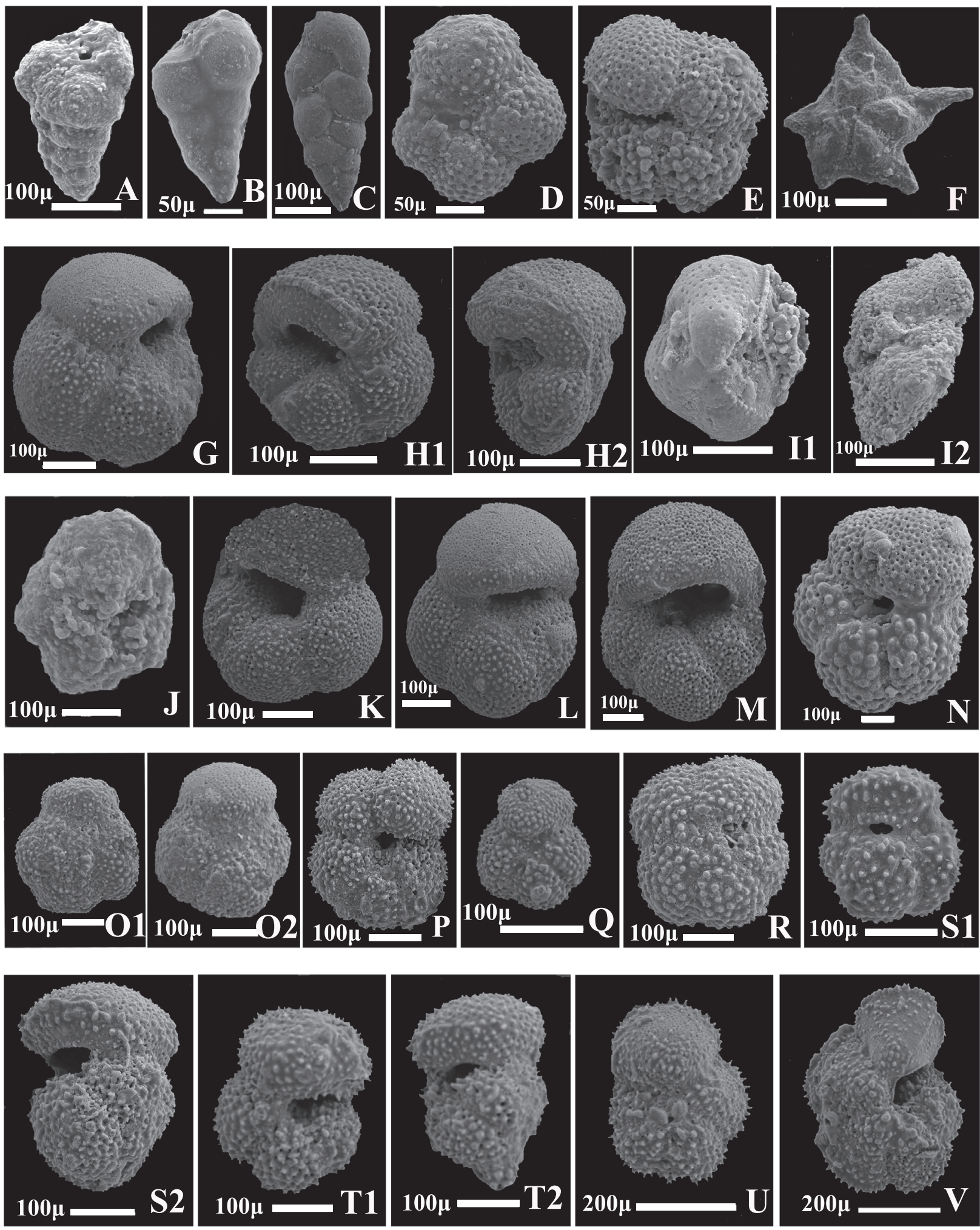

FIGURE 6 (caption on next page). 
the $\mathrm{HO}$ of Morozovelloides crassatus and most of the spinose forms (large Acarininids and Morozovelloides) are synchronous, so the present Zone is coincided with the E13 Zone of Berggren and Pearson (2005) and Wade et al. (2011). In Section $\mathrm{A}$, the species Morozovelloides crassatus and the associated spinose forms are present throughout the section. However, these species and the associated assemblages disappeared after the unconformity between the El Fashn and Beni Suef formations in section $B$, so the exact location of the top of this zone E13 was not found (Figure 4).

Hantkenina assemblages, especially Hantkenina alabamensis and $H$. primitive, are usually recorded within this zone and extend to the overlying Late Eocene zones (Toumarkine and Luterbacher, 1985; Al-Hellou, 2000; Smadi, 2002 and others). In the present studied sections the Hantkenina assemblages are not recorded.

Correlation. This zone was recognized by many authors from the late Middle Eocene of Egypt and the Tehyan Province. Globally, it is correlated with Truncorotaloides (=Acarinina) rohri of Trinidad (Bolli, 1957b; Postuma, 1971), Italy (Bolli, 1972; Toumarkine and Bolli, 1975), Spain (Hillebrandt, 1974), United Arab Emirates (Anan et al., 1992), Israel (Benjamini, 1995), Libya (El-Khoudary, 1980), and Egypt (Bassiouni et al.,1974; Anan, 1979; Samir, 1986; Haggag, 1989b,1990; Selima, 1989; Haggag and Luterbacher, 1991; Abd El-Aziz, 2008; Strougo et al., 2013; Marzouk et al., 2014). It was also equaited with the P.14 Zone (Truncorotaloides rohri / Morozovella spinulosa zone of Berggren et al. (1995) and E.13 Zone (Morozovelloides crassatus zone of Berggren and Pearson (2005); Wade et al. (2011) (Figure 9).

\section{E14. Globigerinatheka semiinvoluta Zone}

Category. Highest-Occurrence Zone.

Definition. This zone was defined by Wade et al. (2011) as a highest-occurrence zone that defined by the biostratigraphic interval between the $\mathrm{HO}$ of the late Middle Eocene Morozovelloides crassatus to the $\mathrm{HO}$ of Globigerinatheka semiinvoluta.

Age. late Middle Eocene -Late Eocene (Bartonian Priabonian).

Assemblages. The most characteristic assemblages recorded from this zone are Globigerinatheka semiinvoluta, Gk. rubriformis, Gk. tropicalis, Turborotalia cerroazulensis, T. pomeroli, T. cunialensis, T. cocoaensis, T. ampliapertura, Dentoglobigerina venezuelana, $D$. pseudovenezuelana, D. galavesi, D. tripartita, Chiloguembelina cubensis, Ch. ototara, Pseudohastegerina micra, $P$. naguawichiensis, $P$. danvillensis, Subbotina praeturritilina, S. corpulenta, S. eocaena, S. angiporoides, S. hagni, S. yaguaensis, S. tecta, S. linaperta, Parasubbotina inaequispira, Globigerinita africana, G. echinata, Globoturborotalita barbula, G. martini, G. praebulloides, G. occlusa, G. gnauki, Acarinina medizzai, Catapsydrax unicavus, C. howei, C. dissimilis, C. cryptomphala, Paragloborotalia opima, P. nana, Tenuitella angustiumbilicata, T.gemma. The most common benthic species recorded in this zone are assemblages of the genera Cancris (C. auriculus, C. danvillensis, C. subconicus), Baggina (B. bradyi), Laevidentalina (L. soluta), Textularia (T. fahmyi, T. recta), Paralabamina (P. lunata), Neoeponides (N. schreibersi), Pararotalia ( $P$. audouini, P. spinigera), Reussella (R. terquemi), Elphidium, Saracenaria, Planulina, Anomalinoides (A. acutus), Cibicidoides (C. yankaulensis), Discorbis (D. bulla, D. vesicularis), and Rosalina (R. quadrata).

FIGURE 6 (figure on previous page). Scanning electron micrographs of planktonic foraminifera species (S = Sample numbers, Fm = Formation). A-Guembelitria oveyi Ansary, 1955, S. 7, El Fashn Fm., section A; B-Chiloguembelina cubensis (Palmer, 1934), S.3, Qurn Member, section B; C-Chiloguembelina ototara (Finlay, 1940), S.5, Qurn Member, section B; D-Paragloborotalia nana (Bolli, 1957), S.37, Tarbul Member, section C; E-Paragloborotalia opima (Bolli, 1957), S.37, Tarbul Member, section C; F-Astrorotalia palmerae (Cushman \& Bermudez,1937), S.34, Tarbul Member, section C; G-Turborotalia centralis (Cushman and Bermudez, 1937), S. 4, El Fashn Fm, section A; H1-H2-Turborotalia cerroazulensis (Cole, 1928), S.41, Tarbul Member, section C; I1-I2-Turborotalia cocoaensis (Cushman, 1928), S.41, Tarbul Member, section C; J-Turborotalia cunialensis (Toumarkine and Bolli, 1970), S.41, Tarbul Member, section C; K-Turborotalia pomeroli (Toumarkine and Bolli, 1970), S. 3, El Fashn Fm, section A; L-Turborotalia increbescens (Bandy, 1949), S. 4, El Fashn Fm, section A; M-Turborotalia ampliapertura (Bolli, 1957), S.11, Qurn Member, section B; N-lgorina broedermani (Cushman and Bermudez, 1949), S. 4, El Fashn Fm, section A; O1-O2 Acarinina bullbrooki (Bolli, 1957), S. 5, El Fashn Fm, section A; P-Acarinina collactea (Finlay, 1939), S. 4, El Fashn Fm, section A; Q-Acarinina matthewsae Blow, 1979, S. 5, El Fashn Fm; R-Acarinina pentacamerata (Subbotina, 1947), S. 5, El Fashn Fm, section A; S1-S2-Acarinina primitiva (Finlay, 1947), S. 5, El Fashn Fm, section A; T1-T2-Acarinina spinuloinflata (Bandy, 1949), S. 7, El Fashn Fm, section A; U-Morozovelloides lehneri (Cushman and Jarvis, 1929), S. 5, El Fashn Fm, section A; V-Morozovelloides crassatus (Cushman, 1925), S. 5, El Fashn Fm, section A. 

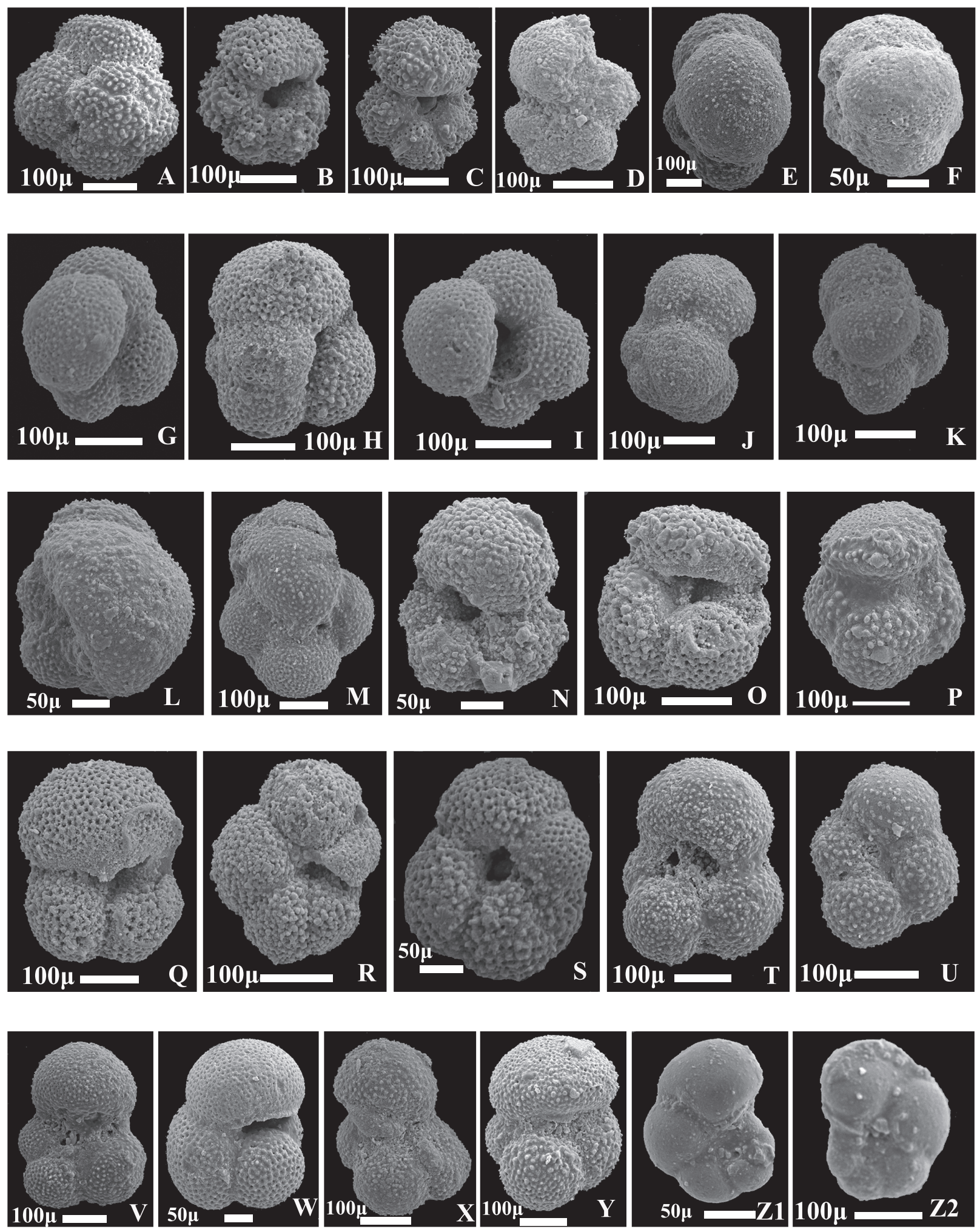

FIGURE 7 (caption on next page). 
Remarks. The present zone occurs in Section B including the whole thickness of the Qurn Member of Beni Suef Formation and most of the Tarbul Member (samples 30-39). It occurs in Section C and represented by samples 1-34 of the Tarbul Member of Beni Suef Formation. It overlies the Morozovelloides crassatus zone and underlies the Globigerinatheka index zone. The lower boundary of the present zone is marked at the highest occurrence of the Morozovelloides crassatus and its associated spinose forms and located at the base of the Qurn Member. However, the upper boundary was traced at the last occurrence of Globigerinatheka semiinvoluta and the first appearance of Turborotalia cunialensis (Figures 2, 5). Berggren et al. (1995) mentioned that the lowest occurrence of Turborotalia cunialensis defined the top of Globigerinatheka semiinvoluta zone (P 15 Zone) and the base of the planktonic P 16 Zone. The Globigerinatheka semiinvoluta zone occurs above the Turborotalia pseudoampliapertura zone in the Upper Eocene rocks of the Fayum province in Egypt (Haggag 1990, 1992). In western Sinai, Abd ElShafy et al. (2007) recorded this zone from the Upper Eocene succession at Wadi Bagha. Strougo et al. (2013) and Marzouk et al. (2014) defined the Globigerinatheka semiinvoluta Subzone (P15b) from the Upper Eocene of the Fayum province.

Toumarkine and Luterbacher (1985), Berggren and Miller (1988), and Berggren et al. (1995) reported that the Globigerinatheka semiinvoluta appeared at younger levels than the extinction of the spinose forams. On the other hand, Pearson and Chiasson (1997), Norris et al. (1997), Wade (2004), Berggren and Pearson (2005), and Wade et al. (2011) reported that the LO of Globigerinatheka semiinvoluta is younger than that was previously recorded by Berggren et al. (1995), where the LO of Gk. semiinvoluta was older than the $\mathrm{HO}$ of Morozovelloides crassatus. In the tropical and subtropical areas, the present zone is distinguished by the Globigerinatheka semiinvoluta and the advanced forms of Turborotalia cerroazulensis lineage, such as Turborotalia cocoaensis, Turborotalia cerroazulensis together with Turborotalia pomeroli, Globigerinatheka tropicalis, Hantkenina alabamensis, $H$. primitiva, and numerous large species of Subbotina and Globigerina. On the other hand, in temperate areas, Globigerinatheka luterbacheri and Globigerinatheka index are abundant, and the zonal marker may be absent (Toumarkine and Luterbacher, 1985).

Correlation. Globally, the age of the Globigerinatheka semiinvoluta zone is late Eocene (Bolli, 1957b; Hillerbandt, 1974; Stainforth et al., 1975; Toumarkine and Luterbacher, 1985; Berggren and Miller, 1988). Moreover, Berggren et al., (1995); Berggren and Pearson (2005); Wade et al., 2011, and Karoui-Yaakoubi (2017) assigned a late Bartonian -Early Priabonian age to this zone. This zone was recorded from northeast Libya (Imam, 1999) and Egypt (Bassiouni et al., 1974; Abddel-kireem, 1985; Haggag, 1989a; Haggag and Bolli, 1996; Abul-Nasr, 1993; Shahin 1998; Abdallah et al., 2003; Abd El-Shafy et al., 2007; Strougo et al., 2013; Marzouk et al., 2014 and others) (Figure 9). It could be correlated with the Globigerapsis semiinvoluta zone of Italy (Bolli and Cita, 1960), Syria (Al-Helou, 1996), Spain (Hillebrandt, 1974), Israel

FIGURE 7 (figure on previous page). Scanning electron micrographs of planktonic foraminifera species A-Acarinina libyaensis El Khoudary, 1977, S. 5, El Fashn Fm, section A; B-Acarinina rohri Bronnimann and Bermudez, 1953, S. 5, El Fashn Fm, section A; C-Acarinina topilensis (Cushman, 1925), S. 5, El Fashn Fm, section A; D-Tenuitella gemma (Jenkins, 1966), S.37, Tarbul Member, section C; E-Globigerinita africana Blow and Banner, 1962, S. 2, El Fashn Fm, section A; F-Globigerinita echinata (Bolli, 1957), S.16, Qurn Member, section B; G-Globoturborotalita martini Blow and Banner, 1962, S.8, Qurn Member, section B; H-Globigerinita pera (Todd, 1957), S. 5, El Fashn Fm; I-Globoturborotalita barbule Pearson and Wade, 2015, S.18, Tarbul Member, section C; J-Catapsydrax cryptomphala (Glaessner, 1937), S.4, Qurn Member, section B; K-Catapsydrax dissimilis (Cushman and Bermudez, 1937), S.5, Qurn Member, section B; L-Catapsydrax howei (Blow and Banner, 1962), S.5, Qurn Member, section B; M-Catapsydrax unicavus (Bolli, Loeblich and Tappan), S.4, Qurn Member, section B; N-Dentoglobigerina galavisi (Bermudez, 1961), S.2, Qurn Member, section B; O-Dentoglobigerina pseudovenezuelana (Blow and Banner, 1962), S.2, Qurn Member, section B; P-Dentoglobigerina venezuelana (Hedberg, 1937), S.12, Qurn Member, section B; Q-Dentoglobigerina tripartita (Koch, 1926), S.41, Tarbul Member, section C; R-Turborotalita carcoselleensis Toumarkine and Bolli, 1975, S.8, Qurn Member, section B; S-Globorotaloides suteri Bolli, 1957, S. 5, El Fashn Fm, section A; T-Subbotina eocaena (Guembel, 1868), S. 6, El Fashn Fm, section A; U-Subbotina hagni (Gohrbandt, 1967), S.10, Qurn Member, section B; VParasubbotina inaequispira (Subbotina, 1953), S.34, Tarbul Member, section B; W-Subbotina linaperta (Finlay, 1939), S. 5, El Fashn Fm, section A; X-Subbotina tecta Pearson and Wade, 2015, S.36, Tarbul Member, section B; Y-Subbotina yeguaensis (Weinzierl and Applin, 1929), S.5, El Fashn Fm, section A; Z1-Pseudohastegerina danvillensis (Howe and Wallace, 1932), S.23, Tarbul Member, section B; Z2-Pseudohastegerina micra (Cole, 1927), S.23, Tarbul Member, section B. 

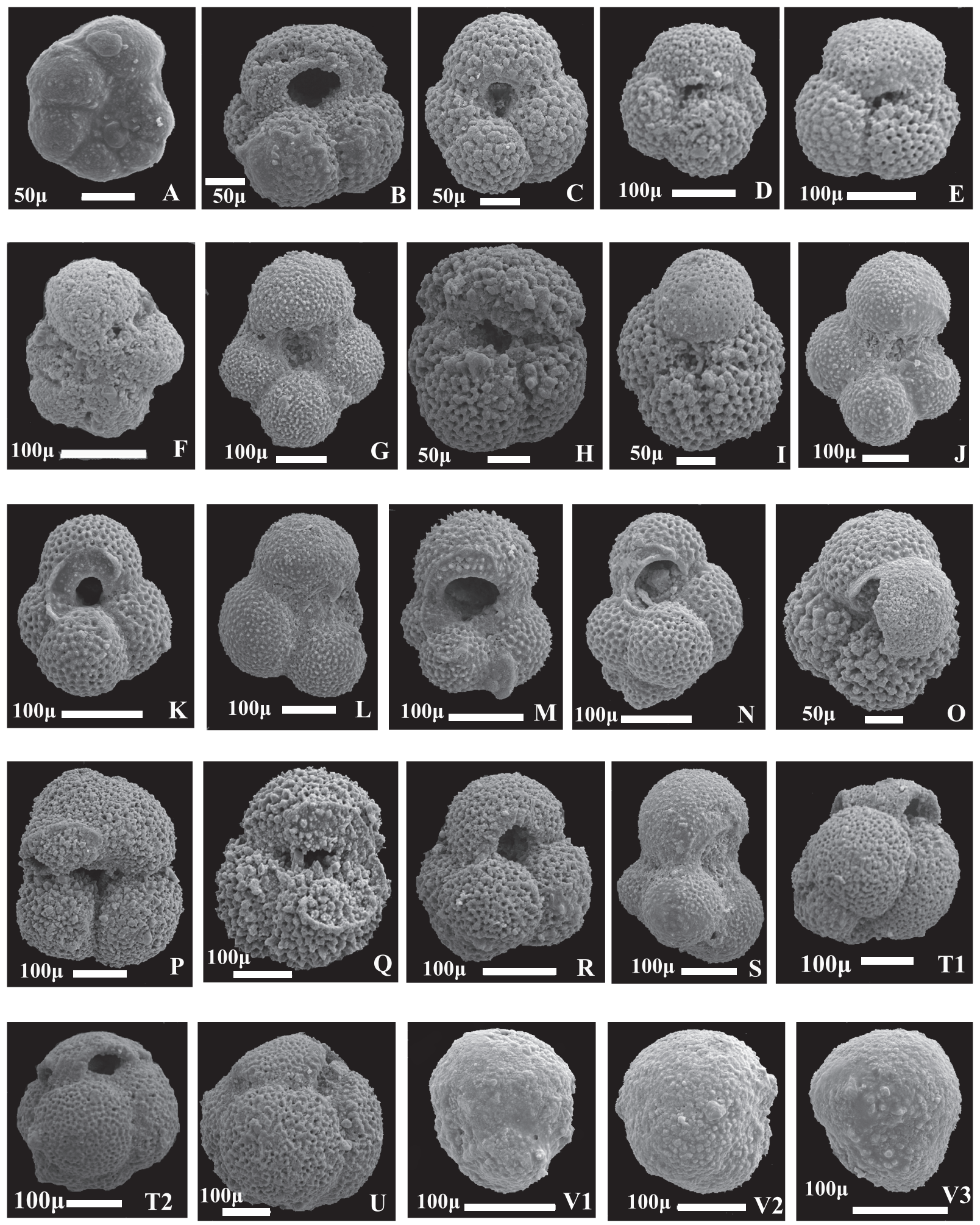

FIGURE 8 (caption on next page). 
(Benjamini, 1980), and Tunisia (Karoui-Yaakoub et al., 2017).

\section{E 15. Globigerinatheka index Zone}

Category. Highest-Occurrence Zone.

Definition. The present zone is defined by Wade et al. (2011) as the interval between the highest occurrence $(\mathrm{HO})$ of Globigerinatheka semiinvoluta and the $\mathrm{HO}$ of Globigerinatheka index. In the present study the nominate species of this zone (Globigerinatheka index) has not appeared, so the upper boundary of this zone is undefined in the studied section and only contains a part of this zone.

Age. Late Eocene (Priabonian).

Assemblages. Thirteen species are identified from the present zone including Turborotalia cerroazulensis, Turborotalia cunialensis, Turborotalia cocoaensis, Subbotina yaguaensis, Dentoglobigerina tripartita, Pseudohastegerina naguewichiensis, Chiloguembelina cubensis, Catapsydrax dissimilis, Globoturborotalita occlusa, Tenuitella angustiumbilicata, Paragloborotalia opima, Paragloborotalia nana, and Tenuitella gemma. The most important benthic foraminiferal species recorded in this zone include assemblage of the genera Cancris (C. auriculus, C. subconicus), Epistomaroides, Rosalina (R. quadrata), Discorbis (D. vesicularis), Paralabamina (P. Iunata), Cibicidoides (C.yankulaensis, C. ocalamus), Pararotalia, Textularia (T. adamsi, T. recta), Lenticulina, Nonionella (N. africana, N. labradorica), and Reussella (R.terquemi).

Remarks. In this study, the Globigerinatheka index zone includes the upper part of the Tarbul Member of the Beni Suef Formation in section C (samples 35-42). The lower boundary of this zone is located at the $\mathrm{HO}$ of Globigerinatheka semiinvoluta and the LO of Turborotalia cunialensis. Meanwhile, the upper boundary is undefined due to the absence of the nominate species (Figures 2, 5). In this study, this zone is recorded for the first time from the Late Eocene of the north Eastern Desert of Egypt. This zone is also characterized by the presence of the slightly keeled and flattened Turborotalia cunialensis and the most highly evolved Turborotalia species; Turborotalia cerroazulensis and Turborotalia cocoaensis. The abundance of large species of Globigerina, Dentoglobigerina (Globoguadrina), Paragloborotalia nana, and very small forms of Pseudohastigerina naguewichiensis characterized this zone.

Correlation. This zone is globally matched with the Late Eocene Turborotalia cerroazulensis zone (Bolli, 1957b; Toumarkine and Luterbacher, 1985) and Turborotalia cunialensis/Cribrohantkenina inflata zone P 16 (Berggren et al., 1995; Mukhopadhyay, 2003). It is also correlated with the Late Eocene Turborotalia cocoaensis and Turborotalia cunialensis zones (Mukhopadhyay, 2005); Globigerinatheka index zone E 15 of Berggren and Pearson (2005) and Wade et al., (2011) and with the Turborotalia cerroazulensis zone of northeast Libya (Imam, 1999). In Egypt, this zone could be correlated with the Late Eocene Globorotalia cerroazulensis Zone in central Sinai (Viotti and ElDemerdash, 1969), Globigerinoides index tropicalis zone in west central Sinai (Abul-Nasr, 1993), Turborotalia cocoaensis zone in north Sinai and Nile Valley (Bassiouni et al., 1974 and Farouk, 2007), and also with Turborotalia cerroazulensis zone in west central Sinai (Abd El-Shafy et al., 2007) and the Fayum area (Haggag, 1990) (Figure 9).

The interval overlies the Globigerinatheka index zone in section $\mathrm{C}$ includes the exposed lower part of the Maadi Formation. This interval is char-

FIGURE 8 (figure on previous page). Scanning electron micrographs of planktonic foraminifera species A-Pseudohastegerina naguewichiensis (Myatliuk, 1950), S.37, Tarbul Member, section B; B-Turborotalia ampliapertura (Bolli, 1957), S.11, Qurn Member, section B; C-Turborotalia cf. ampliapertura Bolli, 1957; S.7, El Fashn Fm, section A; D-Subbotina angiporoides Hornibrook, 1965; S.2, Qurn Member, section B, E-Subbotina minima Jenkins, 1966; S.7, El Fashn Fm, section A; F-Globigerina angustiumbilicata Bolli, 1957; S.41, Tarbul Member, section C, G-Subbotina corpulenta Subbotina, 1953, S.7, El Fashn Fm, section A; H-Globoturborotalita euapertura Jenkins, 1960, S.7, El Fashn Fm, section A; I-Acarinina medizzai Toumarkine and Bolli, 1975, S.4, Qurn Member, section B; J-Globoturborotalita gnauki Blow and Banner, 1962, S.4, Qurn Member, section B; K-Globoturborotalita ouachitaensis Howe and Wallace, 1932, S.2, Qurn Member, section B; L-Globoturborotalita occlusa Blow and Banner, 1962, S.36, Tarbul Member, section C; M-Globoturborotalita praebulloides Blow, 1959, S.2, Qurn Member, section B; N-Subbotina praeturritilina Blow and Banner, 1962, S.4, Qurn Member, section B; O-Globigerina turgida Finlay, 1939, S.31, Tarbul Member, section B; P-Subbotina utilisindex Jenkins and Orr, 1973, S.2, El Fashn Fm; Q-Subbotina senni (Beckmann, 1953), S.3, El Fashn Fm, sec section A,; S-Globigerinatheka tropicalis (Blow and Banner, 1962), S.7, El Fashn Fm, section A; T1-T2-Globigerinatheka kugleri (Bolli, Loeblich and Tappan, 1957), S.6, El Fashn Fm, section A; U-Globigerinatheka mexicana (Cushman, 1925), S.27, Qurn Member, section B; V1-V3-Globigerinatheka semiinvoluta (Keijzer), S.36, Tarbul Member, section B. 
TABLE 1. The planktonic foraminifera species recorded from the studied Eocene sections.

\begin{tabular}{|c|c|c|}
\hline Planktonic foraminifera species & El Fashn Formation & Beni Suef Formation \\
\hline Catapsydrax cryptomphala (Glaessner, 1937) & - & $\mathrm{x}$ \\
\hline Catapsydrax dissimilis (Cushman and Bermudez, 1937) & $\mathrm{x}$ & - \\
\hline Catapsydrax howei (Blow and Banner, 1962) & $\mathrm{x}$ & - \\
\hline Catapsydrax unicavus (Bolli, Loeblich and Tappan 1957) & - & $\mathrm{x}$ \\
\hline Globorotaloides suteri Bolli, 1957a & $\mathrm{x}$ & - \\
\hline Paragloborotalia nana Bolli, 1957a & $\mathrm{x}$ & $\mathrm{x}$ \\
\hline Paragloborotalia opima Bolli, 1957a & $\mathrm{x}$ & $\mathrm{x}$ \\
\hline Parasubbotina inaequispira (Subbotina, 1953) & $x$ & - \\
\hline Tenuitella angustiumbilicata Bolli, 1957 & $\mathrm{x}$ & $\mathrm{x}$ \\
\hline Globoturborotalita euapertura Jenkins 1960 & $\mathrm{x}$ & $x$ \\
\hline Globigerina turgida Finlay, 1939 & $\mathrm{x}$ & $x$ \\
\hline Globoturborotalita barbula Pearson and Wade 2015 & - & $\mathrm{x}$ \\
\hline Globoturborotalita martini (Blow and Banner, 1962) & $x$ & $x$ \\
\hline Globoturborotalita gnauki (Blow and Banner, 1962) & $\mathrm{x}$ & $\mathrm{x}$ \\
\hline Globoturborotalita ouachitaensis (Howe and Wallace, 1932) & $\mathrm{x}$ & $x$ \\
\hline Globoturborotalita occlusa (Blow and Banner, 1962) & $\mathrm{x}$ & $x$ \\
\hline Globoturborotalita praebulloides (Blow, 1959) & $\mathrm{x}$ & $\mathrm{x}$ \\
\hline Subbotina angiporoides(Hornibrook, 1965) & $\mathrm{x}$ & $\mathrm{x}$ \\
\hline Subbotina minima (Jenkins, 1966) & $\mathrm{x}$ & $\mathrm{x}$ \\
\hline Subbotina corpulenta (Subbotina, 1953) & $\mathrm{x}$ & $\mathrm{x}$ \\
\hline Subbotina eocaena (Guembel, 1868) & $\mathrm{x}$ & $\mathrm{x}$ \\
\hline Subbotina hagni (Gohrbandt, 1967) & $\mathrm{x}$ & $\mathrm{x}$ \\
\hline Subbotina linaperta (Finlay, 1939) & $\mathrm{x}$ & $\mathrm{x}$ \\
\hline Subbotina praeturritilina (Blow and Banner, 1962) & $\mathrm{x}$ & $\mathrm{x}$ \\
\hline Subbotina tecta Pearson and Wade, 2015 & - & $\mathrm{x}$ \\
\hline Subbotina senni (Beckmann, 1953) & $\mathrm{x}$ & - \\
\hline Subbotina utilisindex (Jenkins and Orr, 1973) & $\mathrm{x}$ & $\mathrm{x}$ \\
\hline Subbotina yeguaensis (Weinzierl and Applin, 1929) & $\mathrm{x}$ & $\mathrm{x}$ \\
\hline Turborotalita carcoselleensis (Toumarkine and Bolli, 1975) & $x$ & - \\
\hline Globigerinatheka rubriformis (Subbotina, 1953) & $\mathrm{x}$ & $\mathrm{x}$ \\
\hline Globigerinatheka tropicalis (Blow and Banner, 1962) & $\mathrm{x}$ & $x$ \\
\hline $\begin{array}{l}\text { Globigerinatheka kugleri Globigerinatheka kugleri (Bolli, Loeblich } \\
\text { and Tappan 1957) }\end{array}$ & $\mathrm{x}$ & $\mathrm{x}$ \\
\hline Globigerinatheka Mexicana (Cushman, 1925) & $\mathrm{x}$ & $x$ \\
\hline Globigerinatheka semiinvoluta (Keijzer, 1945) & - & $\mathrm{x}$ \\
\hline Acarinina bullbrooki (Bolli, 1957) & $\mathrm{x}$ & - \\
\hline Acarinina collactea (Finlay, 1939) & $\mathrm{x}$ & - \\
\hline Acarinina libyaensis (El Khoudary, 1977) & $\mathrm{x}$ & - \\
\hline Acarinina matthewsae Blow, 1979 & $\mathrm{x}$ & - \\
\hline Acarinina medizzai (Toumarkine and Bolli, 1975) & $\mathrm{x}$ & - \\
\hline Acarinina pentacamerata (Subbotina, 1947) & $\mathrm{x}$ & - \\
\hline Acarinina primitiva (Finlay, 1947) & $\mathrm{x}$ & - \\
\hline Acarinina rohri (Bronnimann and Bermudez, 1953) & $\mathrm{x}$ & - \\
\hline Acarinina spinuloinflata (Bandy, 1949) & $\mathrm{x}$ & - \\
\hline Acarinina topilensis (Cushman, 1925) & $x$ & - \\
\hline
\end{tabular}


TABLE 1 (continued).

\begin{tabular}{|c|c|c|}
\hline Planktonic foraminifera species & El Fashn Formation & Beni Suef Formation \\
\hline Morozovelloides lehneri (Cushman and Jarvis 1929) & $x$ & - \\
\hline Morozovelloides crassatus (Cushman, 1925) & $\mathrm{x}$ & - \\
\hline Astrorotalia palmerae (Cushman and Bermudez 1937) & - & $\mathrm{x}$ \\
\hline Igorina broedermanni (Cushman and Bermudez 1937) & $\mathrm{x}$ & - \\
\hline Dentoglobigerina galavisi (Bermudez, 1961) & $\mathrm{x}$ & - \\
\hline Dentoglobigerina pseudovenezuelana (Blow and Banner, 1962) & $\mathrm{x}$ & $\mathrm{x}$ \\
\hline Dentoglobigerina tripartite (Koch, 1926) & $x$ & $\mathrm{x}$ \\
\hline Dentoglobigerina venezuelana (Hedberg, 1937) & $\mathrm{x}$ & $\mathrm{x}$ \\
\hline Pseudohastigerina danvillensis (Howe and Wallace, 1932) & $\mathrm{x}$ & $\mathrm{x}$ \\
\hline Pseudohastigerina micra (Cole, 1927) & $\mathrm{x}$ & $\mathrm{x}$ \\
\hline Pseudohastigerina naguewichiensis (Myatliuk, 1950) & $\mathrm{x}$ & $\mathrm{x}$ \\
\hline Turborotalia ampliapertura (Bolli, 1957) & $\mathrm{x}$ & $\mathrm{x}$ \\
\hline Turborotalia cf. ampliapertura (Bolli 1975) & $\mathrm{x}$ & $\mathrm{x}$ \\
\hline Turborotalia centralis (Cushman and Bermudez, 1937) & $x$ & $\mathrm{x}$ \\
\hline Turborotalia cerroazulensis (Cole, 1928) & $\mathrm{x}$ & $\mathrm{x}$ \\
\hline Turborotalia cocoaensis (Cushman, 1928) & - & $\mathrm{x}$ \\
\hline Turborotalia cunialensis (Toumarkine and Bolli, 1970) & - & $\mathrm{x}$ \\
\hline Turborotalia pomeroli (Toumarkine and Bolli, 1970) & $\mathrm{x}$ & $\mathrm{x}$ \\
\hline Turborotalia increbescens (Bandy, 1949) & $\mathrm{x}$ & $\mathrm{x}$ \\
\hline Guembelitria oveyi Ansary 1955 & $\mathrm{x}$ & - \\
\hline Chiloguembelina cubensis (Palmer, 1934) & $\mathrm{x}$ & $\mathrm{x}$ \\
\hline Chiloguembelina ototara (Finlay, 1940) & $\mathrm{x}$ & $\mathrm{x}$ \\
\hline Tenuitella gemma (Jenkins, 1966) & & $\mathrm{x}$ \\
\hline Globigerinita africana Blow and Banner, 1962 & $\mathrm{x}$ & $\mathrm{x}$ \\
\hline Globigerinita echinata (Bolli, 1957b) & $x$ & $x$ \\
\hline Globigerinita pera (Todd, 1957) & $x$ & - \\
\hline
\end{tabular}

acterized by an absence of planktonic species. It is equivalent to the benthic foraminiferal Pyrgo elongata zone recorded by Abd El-Gaied et al. (2019) from the studied section. The identified benthic species in this interval includes miliolid, textularid, and nummulitid foraminifera. This interval assigned the Late Eocene age based on its stratigraphic position and the occurrence of the marker small and large benthic foraminifera (Nummulites and Operculina) and macrofossils (Carolia placunoides and other bivalves; large and small size of gastropods, corals and echinoids). The abundance of the miliolids, textularids, and nummulitids with a remarkable extinction of the planktonic foraminifera at this interval of the studied succession was related to fall of the eustatic sea-level that took place at the end of the Late Eocene (Berggren et al., 1985; Keller et al., 1987; Anan 1995, 2007).

\section{Middle / Upper Eocene (Bartonian / Priabonian) Boundary}

Up until now, the Global Stratotype Section and Point (GSSP) for the Middle/Upper Eocene (Bartonian/Priabonian) boundary has not been designated. Generally, in Egypt the Middle -Upper Eocene (Bartonian/Priabonian) boundary was traced at the lowest occurrence of Globigerinatheka semiinvoluta (Strougo, 1992 and 2008; Abd El-Shafy et al., 2007; Strougo et al., 2013 and Marzouk et al., 2014). Some authors placed this boundary at the last appearance of Truncorotaloides (Acarinina) rohri and the associated spinose forms (Haggag, 1986, 1989a, 1989b; Haggag and Luterbacher, 1991; Abd El-Aziz, 2002; Abdallah et al., 2003; Abd El-Gaied and Abd El-Aziz, 2005). Haggag (1992a, b) studied the planktonic foraminiferal groups in the Middle and Upper Eocene succession in different localities of Egypt and 


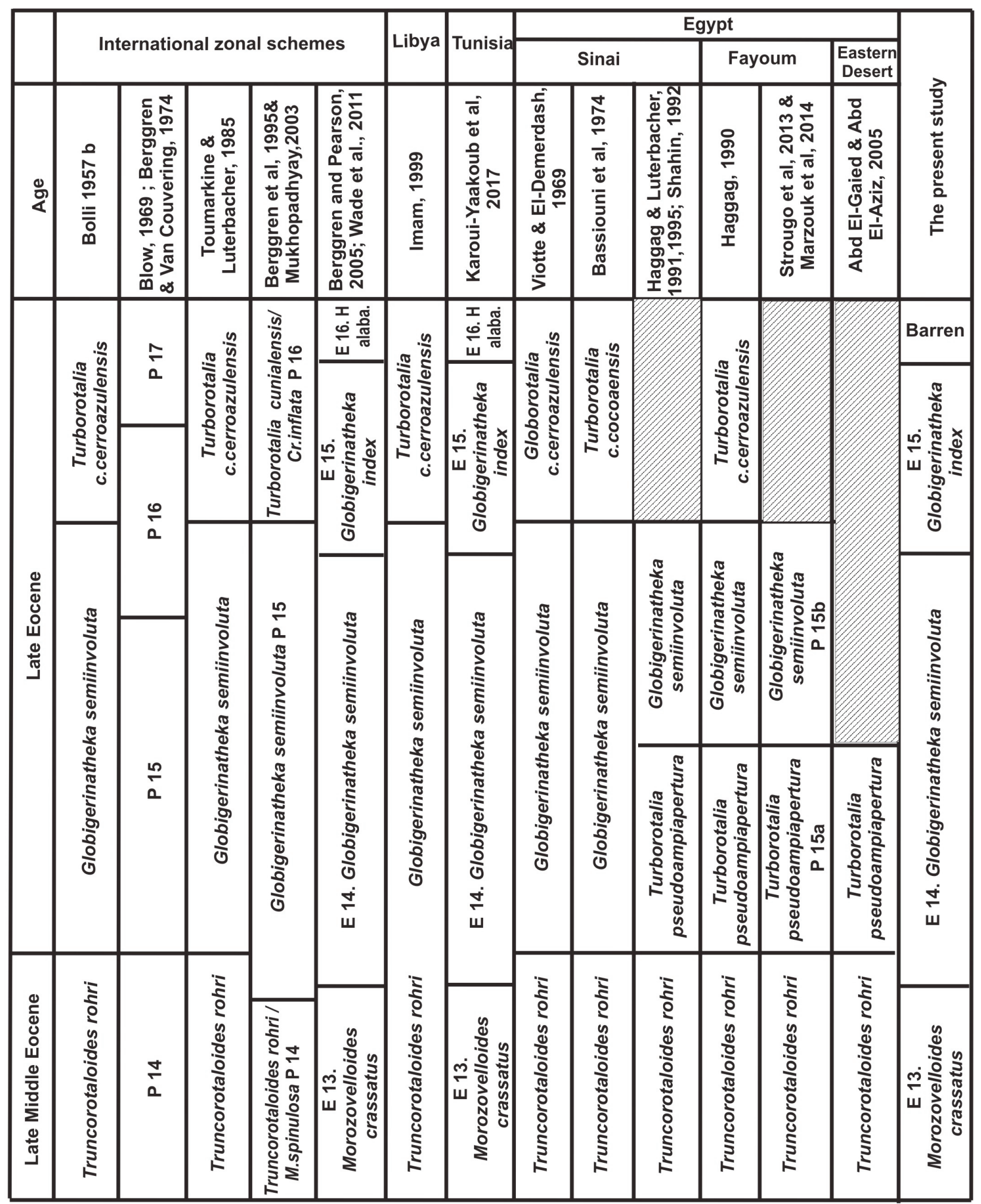

FIGURE 9. Correlation of the recorded planktonic biozones in the study area with the international zonal schemes and those in and outside Egypt. 
recognized that the Middle/Upper Eocene (Bartonian / Priabonian) boundary traced at the top of the Turborotalia pseudoampliapertura zone. However, Aly et al. (2011) and Abd El-Gaied et al. (2019) placed this boundary between the benthic foramineferal Palmula ansaryi zone and the Bulimina jacksonensis zone. Some authors (Blow, 1979; Toumarkine and Luterbacher, 1985; Shahin, 1992; Berggren et al., 1995; Haggag and Bolli, 1996; Mukhopadhyay, 2003 and others) considered the extinction of the middle Eocene spinose planktonic foraminifera as a marker for the boundary between the late Middle and the earliest Upper Eocene in the tropical and Mediterranean reagions. Others considered the first appearance of the Globigerinatheka semiinvoluta simultaneously with the disappearance of the Middle Eocene Truncorotaloides, Morozovellids, and the large Acarinina distinguished the Middle/Upper Eocene boundary (Strougo, 1992, 2008). According to the standard chronostratigraphic scale, the Bartonian/ Priabonian boundary is located either at the P14/ P15 zonal boundary or at the lower part of zone P15 (Toumarkine and Luterbacher, 1985; Berggren et al., 1995). In Egypt and the Middle East, Anan (1994, 2011), Hussein (1998), Helal (2002), Aly et al. (2011), and Abd El-Gaied et al. (2019) placed the Bartonian/Priabonian boundary at the last appearance of the benthic foraminiferal species palmula ansaryi. In the present study, the boundary between the Middle Eocene (Bartonian) and Upper Eocene (Priabonian) was located within the Globigerinatheka semiinvoluta zone (according to the works of Berggren and Pearson (2005), Wade et al., (2011), and Karoui-Yaakoubi (2017). The sedimentary succession at this boundary was characterized by shale and marl intercalations.

\section{PLANKTONIC FORAMINIFERA AND SEA LEVEL CHANGE}

Planktonic foraminifera have a great value in constructing the sea level changes (Hart and Bailey, 1979; Leckie, 1987). Saber and Salama (2017) stated that the Eocene succession exposed to the south of our studied area is deposited under alternative transgressive and regressive cycles that related to the sea-level fluctuations. The vertical and lateral lithological changes besides the planktonic and benthonic ratio in the present study show environmental change from deep to shallow marine environments. Paleodepth obtained from the regression equation of Van der Zwaan et al. (1990) allowed us to reconstruct sea level changes that prevailed during deposition of the Eocene succes- sion. Based on the observed facies changes, the Middle-Upper Eocene succession in the study area can be subdivided into four depositional sequences. The absence of lowstand systems tract of these sequences is probably due to erosional events along the sequence boundaries (Saber and Salama, 2017).

1) Depositional sequence 1 (DS1).This is the older depositional sequence and is of late Middle Eocene (Bartonian) age and is represented by the El Fashn Formation. The age of this sequence was confirmed by its occurrence with the Morozovelloides crassatus Zone. The transgressive systems tract (TST) of sequence 1 was marked by limestone and marl with high $\mathrm{P} / \mathrm{B}$ ratios $(75-89 \%)$ that reflect water depth upto $550 \mathrm{~m}$ (Figure 10) in the upper bathyal environment and indicated the maximum flooding surface. The upper part of the El Fashn Formation at section A and basal part of section $B$ corresponds to the highstand systems tract (HST) that consists of limestone with $P / B$ ratio $57-68 \%$ that indicates shallowing upward in the depositional environments to water depth upto $450 \mathrm{~m}$. This sequence is well correlated with sequence 2 of Saber and Salama (2017). Globally, it was correlated with the third order cycle TA3.6 of Haq et al. (1987) and Bar 1of Hardenbol et al. (1998). The P\% decreased to $57 \%$ at the uppermost part of El Fashn Formation, reflected sea level drop and water depth 340 $\mathrm{m}$ (Figure 10). Bartonian/Priabonian sea level fall was previously described in Egypt (Strougo, 1992; Peters et al., 2009; Sallam et al., 2015; Wanas et al., 2015; Abdel-Fattah et al., 2016; Saber and Salama, 2017). This boundary was also described from the European basins (Hardenbol et al., 1998), southern Israel, and the southeastern Sirt basin (Guirad and Bosworth, 1999). The global eustatic sea level fall is complement with Bartonian/Priabonian boundary (Vail et al., 1977; Haq et al., 1987).

2) Depositional sequence 2 (DS2). This sequence is represented by the Qurn Member of Beni Suef Formation and the lower part of Globigerinatheka semiinvoluta zone (Figures 9, 10A). It is of latest Bartonian -early Late Priabonian age. It was deposited with $\mathrm{P} \%$ of $57-45 \%$ and water depth upto $320 \mathrm{~m}$. It is subdivided into transgressive and highstand systems tracts. The TST of sequence 2 was mainly shale corresponding to the outer 


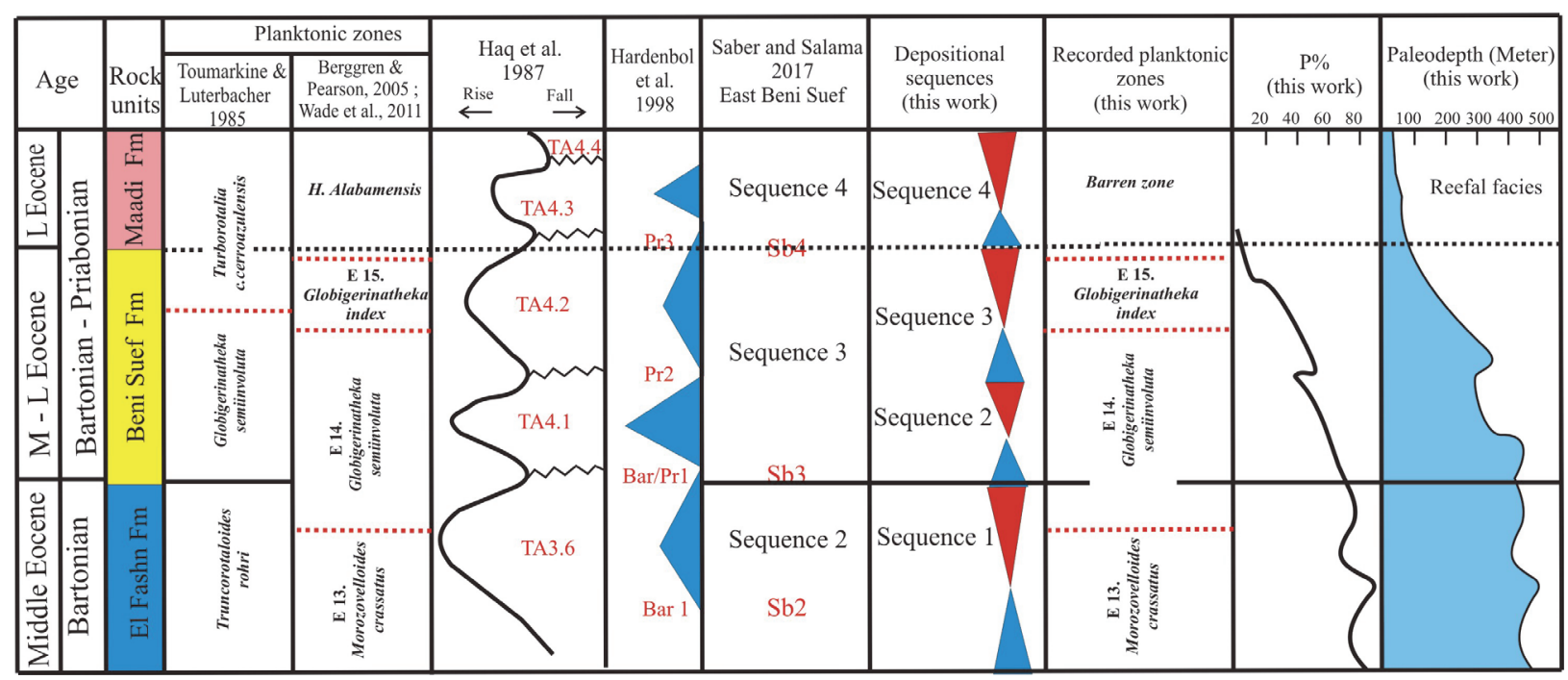

FIGURE 10. Correlation chart shows correlation of the planktonic zones, planktonic foraminiferal ratio (P\%), paleodepth of the studied succession with the tethyan sea level, and depositional sequences as well as the international planktonic zones.

ramp facies of sequence 3 of Saber and Salama (2017). The lowering of sea level began to deposit the high stand systems tract in the form of shallower marl facies at the upper part of Qurn Member (water depth 270 $\mathrm{m})$, reflected by the lowering of the planktonic foraminifera ratio $\mathrm{P} \%$ to $40 \%$. These ratios recorded at the middle part of Globigerinatheka semiinvoluta zone.

3) Depositional sequence 3 (DS3). This sequence corresponds to the topmost part of the Qurn Member and the whole thickness of the Tarbul Member of the Beni Suef Formation, which was represented by the upper part of Globigerinatheka semiinvoluta zone and Globigerinatheka index zone of Priabonian age that coincide with the TST and HST, respectively (Figures 10, 11A-C). The transgressive systems tract is mainly marly facies and characterized with a planktonic ratio $\mathrm{P} \%$ up to $36 \%$ decreasing gradually within the highstand deposits to reach $6 \%$ at the boundary with the overlying sequence. This sequence was well correlated with sequence TA4-2 of Haq et al. (1987) and the lower boundary corresponds to Pr2 boundary of Hardenbol et al. (1998) (Figure 10).

4) Depositional sequence 4 (DS4). It is represented by the upper Eocene Maadi Formation (Figures 10 and 11B). The lowering of sea level leads to form a hardground horizon with Thalassinoids at the top of Beni Suef Forma- tion. This horizon is documented in the Fayum area (Abdel-Fattah et al., 2010, 2016). Also, it is described from the European basins as Pr3 boundary (Hardenbol et al., 1998). Globally, this lowering of sea level was documented between $3^{\text {rd }}$ order cycles TA4.2 and TA4.3 of Haq et al. (1987). The boundary between the Beni Suef and Maadi formations is characterized by a complete absence of planktonic foraminifers that reflects paleowater depth of about $36 \mathrm{~m}$, and the deposition took place in inner shelf environment (Pippèrr and Reichenbacher, 2010; Pippèrr, 2011). The transgressive systems tract deposits are mainly marl and shale rich in benthic foraminifera. Moreover, the Maadi Formation is rich in mega-fossils (Bivalves, gastropods, echinoids), algae and benthic foraminifera (Figure 11D) that live in shallow marine environment (Murray and Alve, 1999; Kooistra et al., 2002; James and Bone, 2011; Granier, 2012; Reuter et al., 2012; Sarkar, 2016). Also, the Maadi Formation is distinguished by the first appearance of solitary and colonial corals that were not observed in the underlying Eocene rocks of the studied sequence and some of the neighboring areas. These corals and their faunal associations prevailed as a small patch reef formed during the highstand systems tract of sequence 4 . This view shows a great accordance with the observation that was concluded by Scheibner et al. (2000) from the 

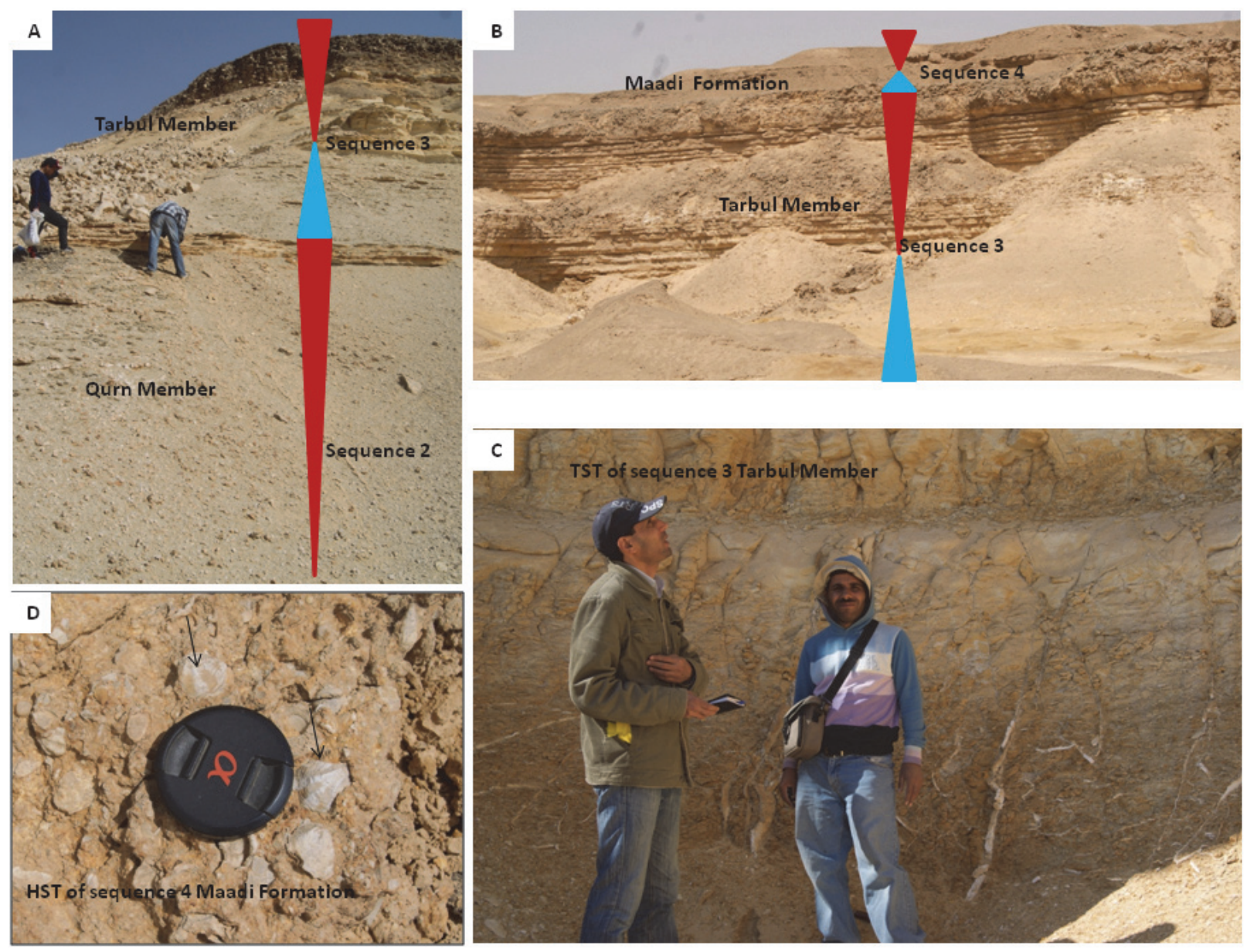

FIGURE 11. Field photos showing the depositional sequences, A shows the boundary between Qurn (sequence 2) and Tarbul members (sequence 3); B shows the depositional sequence 3 representing Tarbul Member and the overlying sequence 4 of Maadi Formation; $C$ shows shale and marly facies that represented the transgressive systems tracts of sequence 3; D shows the reefal facies with bivalvia (black arrows) that represented the highstand systems tracts (HST) of sequence 4 .

Galala Mountains, north Eastern Desert, Egypt. Morsilli et al. (2012) stated that the Eocene corals are largely found as reef patches. The well-preserved corals were considered as important tool to reflect the past sea level, occupying shallow marine settings with water depth $40 \mathrm{~m}$ (Carpenter et al., 2008; Woodroffe and Webster, 2014; Hibbert et al., 2016). Generally, the Middle to late Eocene age was assigned as the time of coral diversity and abundance in the Tethyan area (Fagerstrom, 1987; Budd, 2000; Geel, 2000; Perrin, 2002; Nebelsick et al. 2003, 2005; Morsilli et al., 2012; Król et al., 2017).

\section{DISCUSSION}

The deposition depth of the El Fashn Formation was deeper than the overlying formations, which was indicated by the highest percentage of planktonic foraminifera $(\mathrm{P} \%=75-89 \%)$. The Beni Suef Formation was deposited in inner to middle shelf environment with moderate P \% (57-45 \% for the Qurn Member and 6-36\% for the Tarbul Member). The Maadi Formation was deposited in an elevated area, indicated by a complete disappearance of planktonic foraminifera and the high abundance of carbonate producers of large benthic foraminifera, corals, and algae that need light for photosynthesis process. A significant biotic turnover in the muricate planktonic foraminiferal genera occurred in the late Middle Eocene with a prominent decline in the Acarininids lineage and 
the extinction of the Morozovellids. This turnover event was associated with the weakening of photosymbiotic partnerships with algae and the increased surface water productivity (Wade, 2004). Barr and Berggren (1980) mentioned that the disappearance of the Truncorotalids and Morozovellids at the end of the late Middle Eocene are due to ecological changes (shallowing) or to preservational conditions. The previous studies on the spinose planktonic foraminiferal genera detected that these genera were prominent surface dwellers for the tropical and subtropical fauna, and their rapid global extinction through the late Middle Eocene was abrupt (Pearson et al. 1993; Toumarkin and Luterbacher, 1985; Wade, 2004; Cotton et al., 2017). These extinction levels have been widely used in global biostratigraphic schemes (Blow, 1969; Toumarkine and Luterbacher, 1985; Berggren and Pearson, 2005; Wade et al., 2011). The abundance of the miliolids and nummulitids with a remarkable extinction of the planktonic foraminifera may be related to the fall of the eustatic sea level that occurred in the Late Eocene (Berggren et al., 1985; Keller et al., 1987; Anan, 1995, 2007). Abdelghany (2002) mentioned that this global regression may be due to a tectonic disturbance and the drop in sea level.

\section{CONCLUSIONS}

The stratigraphy and the planktonic foraminifera of the Middle-Upper Eocene successions at Beni Suef -El Zafaarana District, north Eastern Desert, Egypt, were studied in detail in this work. Lithologically, the studied sequence was described well and could be subdivided into three lithostrati- graphic units covering a time interval from the late Middle to Late Eocene. These rock units are from base to top: the El Fashn (late Middle Eocene), the Beni Suef (latest Middle-Late Eocene), and the Maadi formations (Late Eocene).

The investigation of the microfaunal content of 97 rock samples collected carefully from three exposed sections resulted in the identification of seventy planktonic foraminiferal species belonging to 20 genera and seven families.

The vertical distribution of the estimated species enabled us to recognize three planktonic biozones arranged from base to top as: Morozovelloides crassatus zone (late Middle Eocene) including the El Fashn Formation, Globigerinatheka semiinvoluta zone (late Middle Eocene -early Late Eocene) and Globigerinatheka index zone (Late Eocene) including the Beni Suef Formation. The examination of the samples of the Maadi Formation yielded common to abundant representation of large and small benthic foraminifera and complete absence of the planktonic species.

Based on the changes in planktonic ratio and the paleowater depth, the studied Eocene successions are subdivided into four depositional sequences.

\section{ACKNOWLEDGEMENTS}

The authors would like to thank Prof. G. Abdel-Gawad from the Geology Department, Faculty of Sciences (Beni-Suef University) for his help in the field work. We would like to thank our editors A, Elewa, C. Haug, and our reviewers for taking time in this article.

\section{REFERENCES}

Abd El-Aziz, M.S. 2002. Stratigraphy of the Eocene sequences of Fayoum -Minia district (new Road) Egypt. Ph.D. Thesis, Faculty of Sciences Cairo University Fayoum Branch.

Abd El-Aziz, M.S. 2008. Planktonic foraminiferal study of the Middle-Upper Eocene rocks at El Alalma - Gebel Tarbul, Northeast-Beni Suef area, Egyptian Journal of Paleontology, 8:11-48.

Abd El-Gaied, I.M. and Abd El-Aziz, S.M. 2005. Middle and Late Eocene planktonic foraminiferal study of northeast Beni Suef area, Egypt. 4th International Conference on the Geology of Africa, Assiut University, 1:657-687.

Abd El-Gaied, I.M., Salama, Y.F., Saber, S.G., and Sayed, M.M. 2019. Benthic foraminiferal communities of the Eocene platform, north Eastern Desert, Egypt. Journal of African Earth Sciences, 151:121-135. https://doi.org/10.1016/j.jafrearsci.2018.12.007

Abd El-Shafy, E., Fawal, F.M., Nassif, M.S., and Matter, Y.E. 2007. Foraminiferal biostratigraphy of the Eocene exposures between Wadi Bagha and Wadi Matulla, west central Sinai, Egypt. Proceedings of the $8^{\text {th }}$ Conference, Geology of Sinai for Development, Ismailia, p. 91-125. 
Abdallah, A.M., Helal, S.A., and Abdel Aziz, S.M. 2003. Planktonic foraminiferal biostratigraphy of the Eastern Fayum depression, Egypt. 3rd International Conference of Geology Africa, 1:571-598.

Abdel-Fattah, Z. 2018. Bioerosion in the middle Eocene larger foraminifer Nummulites in the Fayum depression, Egypt. Proceedings of the Geologists' Association, 129(6):774-781. https://doi.org/10.1016/j.pgeola.2018.08.003

Abdel-Fattah, Z.A., Gingras, M.K., Caldwell, M.W., and Pemberton, S.G. 2010. Sedimentary environments and depositional characteristics of the middle to upper Eocene whale-bearing succession in the Fayum Depression, Egypt. Sedimentology, 57:446-476. https://doi.org/ 10.1111/j.1365-3091.2009.01091.x

Abdel-Fattah, Z.A., Gingras, M.K., Caldwell, M.W., Pemberton, S.G., and MacEachern, J.A. 2016. The Glossifungites ichnofacies and sequence stratigraphic analysis: a case study from middle to upper Eocene successions in Fayum, Egypt. Ichnos, 23(3-4):157-179. https:// doi.org/10.1080/10420940.2016.1185010

Abdelghany, O. 2002. Biostratigraphy (Turborotalia cunialensis/Cribrohantkenina inflata Concurrent-Range Zone, P16) of the Late Eocene Dammam Formation, west of the Northern Oman Mountains. Micropaleontology, 48:209-221. https://doi.org/10.1661/00262803(2002)048[0209:btccic]2.0.co;2

Abdel-Kireem, M.R., 1985. Planktonic foraminifera of Mokattam Formation (Eocene) of Gebel Mokattam, Cairo, Egypt. Revue de Micropaleontologie, 28(2):77-96.

Abul-Nasr, R.A. 1993. Re-evaluation of the Middle-Upper Eocene Biostratigraphy of West Central Sinai. Middle East Research Center, Ain Shams University, Earth Sciences Series, 7:153-166.

Al-Helou, R. 1996. The Paleogene in Syria. National Committee of Damascus, 2-8.

Al-Helou, R. 2000. The stratigraphy of Eocene and Oligocene in the anti-Lebanon. $5^{\text {th }}$ International Conference of Geology Arab World Cairo University, 3:1377-1392.

Aly, H.A., Abd El-Aziz, S.M., and Abd El-Gaied, I.M. 2011. Middle and Upper Eocene benthic foraminifera from Wadi Bayad El Arab-Gebel Homret Shaibon area, northeast Beni Suef, Nile Valley, Egypt. Egyptian Journal of Paleontology, 11:79-131.

Anan, H.S. 1979. Stratigraphical and micropaleontological study on some Lower Tertiary rocks in Egypt. Ph.D. Thesis, Faculty of Sciences Ain Shams University Cairo.

Anan, H.S., Bahr, S. A., Bassiouni, M.A., and Hamdan, A.A. 1992. Contribution to Early Eocene -Oligocene biostratigraphy of Gebel Hafit succession, United Arab Emirates. M.E.R.C. Ain Shams University, Earth Science Series, 6:225-247.

Anan, H.S. 1994. Benthic foraminifera around Middle/Upper Eocene boundary in Egypt. Ain Shams University, Earth Sciences Series, 8:210-233.

Anan, H.S. 1995. Late Eocene biostratigraphy of Jabals Malaqetand Mundassa of Al Ain region, United Arab Emirates. Revue de Micropaleontologie, 38:3-14.

Anan, H.S. 2007. Paleontology and biostratigraphical remarks on some diagnostic Tethyan benthic foraminifera. $2^{\text {nd }}$ International Conference on the Geology of the Tethys, Cairo University, II:303-308.

Anan, H.S. 2011. Paleontological and paleoenvironment, paleogeography and stratigraphic value of the Maastrichtian, Paleogene and Recent foraminiferal species of Anan in the Middle East. Egyptian Journal of Paleontology, 11:4-78.

Ansary, S.E. 1955. Report on the foraminiferal fauna from the Upper Eocene of Egypt. Public Institute of Desert, Egypt, 6:160.

Bandy, O.L. 1949. Eocene and Oligocene foraminifera from Little Stave Creek, Clarke Country. Alabama. Bulletins of American Paleontology, 32(131):1-207.

Barr, F.T. and Berggren, W.A. 1980. Lower Tertiary biostratigraphy and tectonics of northeastern Libya, p. 163-192. In Salem, M.J. and Busrewil, M.T. (eds.), The Geology of Libya. Academic Press, London.

Bassiouni, M.A., Boukhary, M.A., and Abdelmalik, W.M. 1974. Litho-and biostratigraphy of Middle and Upper Eocene rocks in the Minia -Beni Suef reach of the Nile Valley, Egypt. 6th African Micropaleontogy Collection Tunisia, 28/3:115-153.

Bassiouni, M.A., Boukhary, M.A., and AbdelMalik, W.M. 1975. Microfacies and faunal analysis of the Eocene rocks in the Minia-Beni Suef Reach of the Nile Valley and their paleoecologic significance. 9th Arab Petroleum Congress Dubai, 106(B-3):1-23.

Beckmann, J.P. 1953. Die foraminifera der Oceanic Formation (Eocaen -Oligocaen) von Barbados, KI. Antillen. Ecological Geologica Helv, 46(3):301-412. 
Benjamini, C. 1980. Planktonic foraminiferal biostratigraphy of the Avedat Group Eocene in the Northern Negev, Israel. Journal of Paleontology, 54:325-358.

Benjamini, C. 1995. Planktonic foraminiferal distribution and zonal stratigraphy, p. 33-40. In Schaub, H., Benjamini, Ch., and Moshkovitz, Sh. (eds.), The Biostratigraphy of the Eocene of Israel. Basel Kommission der Schweizerischen Paläontologischen Abhandlungen.

Berggren, W.A. and Van Couvering, J.A. 1974. The late Neogene. Biostratigraphy, geochronology and paleoclimatology of the last 15 million years in marine and continental sequences. Palaeogeography, Palaeoclimatology, Palaeoecology, 16(1-2):1-215.

Berggren, W.A., Kent, D.V., and Flynn, J.J. 1985. Paleogene geochronology chronostratigraphy. In Snelling, N. J. (ed.), The Chronology of the Geological Record. Geological Society of London Memoir, 10:141-195.

Berggren, W.A. and Miller, K.G. 1988. Paleogene tropical planktonic foraminiferal biostratigraphy and magnetobiochronology. Micropaleontology, 34:362-380.

Berggren, W.A., Kent, D.V., Swisher III, C.C., and Aubry, M.P. 1995. A revised Cenozoic geochronology and chronostratigraphy, p. 129-212. In Berggren, W.A., Kent, D.V., Aubry, M.P., and Hardenbol, J. (eds.), Geochronology, Time Scales, and Global Stratigraphic Correlation. SEPM Special Publication 54.

Berggren, W.A. and Pearson, P.N. 2005. A revised tropical to subtropical Paleogene planktonic foraminifera zonation. Journal of Foraminiferal Research, 35(4):279-298. https://doi.org/ 10.2113/35.4.279

Bermudez, P.J. 1961. Contribution al estudio de las Globigerinidae de la region Carbie-Antillana (Paleocene recientc). Bulletin Geology Venezuela Publicaton Especial, 3:1119-1393.

Bishay, Y. 1966. Studies on the large foraminifera of the Eocene (the Nile Valley between Assiut and Cairo and SW Sinai). Ph.D. Thesis, Alexandria University, Egypt.

Blow, W.H. 1959. Age, correlation and biostratigraphy of the Upper Tocuyo (San Lorenzo) and Pozon formations, Eastern Falcon, Venezuela. Bulletins of American Paleontology, 39(178):67-251.

Blow, W. H. and Banner, F.T. 1962. The mid-Tertiary (Upper Eocene to Aquitanian) Globigerinaceae, p. 61-151. In Eames, F. E., Blow, W.H., and Clarke, W.J. (eds.), Fundamentals of Mid-Tertiary Stratigraphical Correlation. Cambridge University Press, Cambridge.

Blow, W.H. 1969. Late Middle Eocene to Recent planktonic foraminiferal biostratigraphy, p. 199422. In Bronnimann, P. and Renz, H.H (eds.), Proceedings of the First International Conference on Planktonic Microfossils, Geneva, 1967. E.J. Brill, Leiden.

Blow, W.H. 1979. The Cainozoic Globigerinida: A study of the Morphology, Taxonomy, Evolutionary Relationships and the Stratigraphical Distribution of Some Globigerinida. E.J. Brill, Leiden.

Bolli, H.M., Loeblich, A.R., and Tapann, H. 1957. Planktonic foraminifera families Hantkeninidae, Orbulinidae, Globorotaliidae and Globotruncanidae. Bulletin of the United States National Museum, 215:3-50.

Bolli, H.M. 1957a. The genera Globigerina and Globorotalia in the Paleocene-Lower Eocene Lizard Springs Formation of Trinidad, B.W.I. Bulletin of the United States National Museum, 215:155-172.

Bolli, H.M. 1957b. Planktonic foraminifera from the Eocene Navet Formation and San Fernando Formations in Trinidad. B.W.I. Bulletin of the United States National Museum, 215:61-82.

Bolli, H.M. and Cita, M.B. 1960. Upper Cretaceous and Lower Tertiary planktonic foraminifera from the Pademo section, North Italy. 1st International Geology Congress, p. 150-161.

Bolli, H.M. 1972. The genus Globigerinatheka Bronnimann. Journal of Foramineferal Research, 2(3):109-136.

BouDagher-Fadel, M. 2012. Biostratigraphic and Geological Significance of Planktonic Foraminifera. Developments in Palaeontology \& Stratigraphy, 22. Elsevier, Amsterdam.

Bronnimann, P. and Bermudez, P.J. 1953. Truncorotaloides, a new foraminiferal genus from the Eocene of Trinidad. BWI Journal of Paleontology, 27:817-820.

Budd, A.F. 2000. Diversity and extinction in the Cenozoic history of Caribbean reefs. Coral Reefs, 19:25-35. https://doi.org/10.1007/s003380050222

Carpenter, K.E., Abrar, M., Aeby, G., Aronson, R.B., Banks, S., Bruckner, A., Chiriboga, A., Cortes, J., Delbeek, J.C., DeVantier, L., Edgar, G.J., Edwards, A.J., Fenner, D., Guzman, H.M., Hoeksema, B.W., Hodgson, G., Johan, O., Licuanan, W.Y., Livingstone, S.R., Lovell, 
E.R., Moore, J.A., Obura, D.O.,Ochavillo, D., Polidoro, B.A., Precht, W.F., Quibilan, M.C., Reboton,C., Richards, Z.T., Rogers, A.D., Sanciangco, J., Sheppard, A., Sheppard, C., Smith, J., Stuart, S., Turak, E., Veron, J.E.N., Wallace, C., Weil, E., and Wood, E. 2008. Onethird of reef-building corals face elevated extinction risk from climate change and local impacts. Science, 321:560-563.

Cole, W.S. 1927. A foraminiferal fauna from the Guayabal Formation in Mexico. Bulletins of American Paleontology, 14:1-46.

Cole, W.S. 1928. A foraminiferal fauna from the Chapapote Formation in Mexico. Bulletin American Paleontology, 14:3-32.

Cotton, L.J., Zakrevskaya, E.Y., Boon, A.V., Asatryan, G., Hayrapetyan, F., Israyelyan, A., Krijgsman,W., Less, G., Monechi, S., Papazzoni, C.A., Pearson, P.N., Razumovskiy, A., Renema, W., Shcherbinina, E., and Wade, B .S. 2017. Integrated stratigraphy of the Priabonian (Upper Eocene) Urtsadzor section, Armenia. Newsletters on Stratigraphy, 50(3):269-295. https://doi.org/10.1127/nos/2016/0313

Cushman, J.A. 1925. Some new foraminiferal from the Velasco shale of Mexico. Contributions from the Cushman Laboratory for Foraminiferal Research, 1:18-23.

Cushman, J.A. 1928. Additional foraminifera from the Upper Eocene of Alabama. Contributions from the Cushman Laboratory for Foraminiferal Research, 4:73-79.

Cushman, J.A. and Jarvis, P.W. 1929. New foraminifera from Trindad. Contributions from the Cushman Laboratory for Foraminiferal Research, 5:6-17.

Cushman, J.A. and Bermudez, P. 1937. Further new species of foraminifera from the Eocene of Cuba. Contributions from the Cushman Laboratory for Foraminiferal Research, 13:1-29.

Darabi, G., Moghaddam, I. M., Sadeghi, A., and Yusefi, B. 2018. Planktonic foraminifera and sea-level changes in the upper Cretaceous of the Gurpi Formation, Lorestan basin, SW Iran. Journal of African Earth Sciences, 138:201-218. https://doi.org/10.1016/ j.jafrearsci.2017.11.011

El Ayyat, A.M ., Obaidalla, N.A. 2016. The impact of the Syrian Arc Orogeny on the Early Paleogene rocks, western shoulder of the Gulf of Suez, Egypt. Palaeogeography, Palaeoclimatology, Palaeoecology, 454:30-53. https://doi.org/10.1016/j.palaeo.2016.04.011

El Khoudary, R.H. 1977. Truncorotaloides libyaensis, a new planktonic foraminifera from Jabal Al Akhdar (Libya). Revista Española de Micropaleontología, 9:326-336.

El Khoudary, R.H. and Helmdach, F. 1980. Biostratigraphic studies on the Middle Eocene of the northern escarpment of Al Jabal Al Akhdar, NE. Libya. Journal of Faculty of Petroleum and Mining Engineering, Al Fateh University Tripoli, Libya, 2(1):35-46.

El-Dawy, M.H. and Dakrory, A.M. 2005. Biostratigraphy and paleoecology of the Middle Eocene benthic foraminifers of East Beni Suef area, Nile Valley, Egypt. 4th International Conference on the Geology of Africa, Assiut, Egypt, 1:623-656.

Ernst S.R. and Van Der Zwaan, G.J. 2004. Effects of experimentally induced raised levels of organic flux and oxygen depletion on a continental slope benthic foraminiferal community. Deep-Sea Research, 51:1709-1739.

Fagerstrom, J.A. 1987. The Evolution of Reef Communities. Wiley, New York.

Farouk, S. 2007. On the occurrence of a Late Eocene "Turborotalia cerroazulensis cocoaensis zone” around Gabal Libni, northern Sinai, Egypt. Egyptian Journal of Paleontology, 7:59-66.

Finlay, H.J. 1939. New Zealand foraminifera key species in stratigraphy. Transactions and Proceedings of the Royal Society of New Zealand, 69(1):89-128.

Finlay, H. J. 1940. New Zealand foraminifera: key species in stratigraphy, No. 4. Transactions and Proceedings of the Royal Society of New Zealand, 70(1):448-472.

Finlay, H.J. 1947. New Zealand foraminifera, key species in stratigraphy. New Zealand Journal of Science Technology, 28(5):259-292.

Geel, T. 2000. Recognition of stratigraphic sequences in carbonate platform and slope deposits: Empirical models based on microfacies analysis of Palaeogene deposits in southeastern Spain. Palaeogeography, Palaeoclimatology, Palaeoecology, 155:211-238. https://doi.org/ 10.1016/s0031-0182(99)00117-0

Glaessner, R.M.F. 1937. Plankton foraminiferen der kreide und dem Eozaen und ihre stratigraphische Bedeutung. Moscow University, Laboratory Paleontology, studies Micropaleontogy, 1:27-46.

Gohrbandt, K.H. 1967. Some new planktonic foraminiferal species from the Austrian Eocene. Micropaleontology, 13:319-326. 
Granier, B. 2012. The contribution of calcareous green algae to the production of limestones: a review. In Basso, D. and Granier, B. (eds.), Calcareous algae and global change: from identification to quantification. Geodiversitas, 34:35-60. https://doi.org/10.5252/g2012n1a3

Guembel, C.W. 1868. Beiträge zur Foraminiferenfauuna der nord-alpinen Eocängebilde. Abhandlungen der Königlich Preussischen Akademie der Wissenschaften, 10:581-730.

Guirad, R. and Bosworth, W. 1999. Phanerozoic geodynamic evolution of northeastern Africa and the northwestern Arabian platform. Tectonophysics, 315:73-108. https://doi.org/ 10.1016/s0040-1951(99)00293-0

Haggag, M.A. 1986. Middle Eocene planktonic foraminifera from Beni Suef area, Egypt. Ain Shams University Science Research Series, 6:59-80.

Haggag, M.A., and Anan, H.S. 1987. Middle Eocene planktonic foraminifera from the Maghagha area, Egypt. Ain Shams Science Bulletin, 25(B):149-174.

Haggag, M.A. 1989a. Evaluation of the planktonic foraminiferal groups around the Middle/Upper Eocene boundary in Egypt. Ain Shams University Science Research Series, 3:184-196

Haggag, M.A. 1989b. Planktonic foraminiferal zonation and evolutionary groups of the Middle Eocene in the Nile Valley, Egypt. Neues Jahrbuch für Geologie und Paläontologie, 178:109132.

Haggag, M.A. 1990. Globigerina pseudoampliapertura Zone, a new Late Eocene planktonic foraminiferal zone (Fayoum area, Egypt). Neues Jahrbuch für Geologie und Paläontologie, 5:295-307. https://doi.org/10.1127/njgpm/1990/1990/295

Haggag, M.A. and Luterbacher, H.P. 1991. Middle Eocene planktonic foraminiferal groups and biostratigraphy of the Wadi Nukhul section, Sinai, Egypt. Neues Jahrbuch für Geologie und Paläontologie, 6:319-334. https://doi.org/10.1127/njgpm/1991/1991/319

Haggag, M.A. 1992b. A comprehensive Egyptian Middle / Upper Eocene planktonic foraminiferal zonation. Egyptian Journal of Geology, 36:97-118.

Haggag, M.A. 1992a. Planktonic foraminiferal groups and zonation of the Paleocene/Eocene of the South Galala and environs. Egyptian Journal of Geology, 35(1-2):37-50.

Haggag, M.A. and Bolli, H.M. 1995. Globigerinatheka index aegyptiaca, a new Late Eocene planktonic foraminiferal subspecies from Fayoum, Egypt. Revista Española de Micropaleontología, 27:143-147.

Haggag, M.A. and Luterbacher, H.P. 1995. The Turborotalia pseudoampliapertura lineage in the Eocene of the Wadi Nukhul section, Sinai, Egypt. Revue de Micropaleontogie, 38(1):37-47. https://doi.org/10.1016/s0035-1598(95)90234-1

Haggag, M.A. and Bolli, H.M. 1996. The origin of Globigerinatheka semiinvoluta (Keijzer), Upper Eocene Fayoum area, Egypt. Neues Jahrbuch für Geologie und Paläontologie, 6:365-374. https://doi.org/10.1127/njgpm/1996/1996/365

Haq, B.U., Hardenbol, J., and Vail, P. 1987. Chronology of fluctuating sea levels since the Triassic. Science, 235:1156-1167. https://doi.org/10.1126/science.235.4793.1156

Hardenbol, J., Thierry, H., Farley, M.B., Jacquin, T., de Graciansky, P., and Vail, P.R. 1998. Mesozoic and Cenozoic sequence chronostratigraphic framework of European basins, p. 313. In de Graciansky, P.C., Hardenbol, J., Jacquin, T., and Vail, P.R. (eds.), Mesozoic and Cenozoic Sequence Stratigraphy of European Basins. SEPM Special Publication 60. https://doi.org/10.2110/pec.98.02.0003

Hart, M.B. and Bailley, H. W. 1979. The distribution of planktonic Foraminiferida in the MidCretaceous of NW Europe. In Wiedmann, J. (ed.), Aspekte der Kreide Europas. International Union of Geological Sciences, Series A, 6:527-542.

Hedberg, H.D. 1937. Foraminifera of the middle Tertiary Carapita Formation of northeastern Venezeula. Journal of Paleontology, 8:661-697.

Helal, S. A., 2002. Contribution to the Eocene benthic Foraminifera and Ostracoda of the Fayoum Depression, Egypt. Egyptian Journal of Paleontology, 2:105-155.

Hibbert, F.D., Rohling, E.J., Dutton, A., Williams, F.H., Chutcharavan, P.M., Zhao, C., and Tamisiea, M.E. 2016. Coral indicators of past sea-level change: A global repository of Useries dated benchmarks. Quaternary Science Reviews, 145:1-56. https://doi.org/10.1016/ j.quascirev.2016.04.019

Hillebrandt, A.V. 1974. Bioestratigrafia de Paleógeno en el Sureste de Espana (Provincias de Murica Y Alicante). Cuadernos de Geología, 5:135-153.

Hornibrook, N.D.B. 1965. Globigerina angiporoides n. sp. from the Upper Eocene and the Lower Oligocene of New Zealand and the status of Globigerina angipora Stache, 1865. New Zealand Journal of Geology and Geophysics, 8:834-838. 
Howe, H.V. and Wallace, W.E. 1932. Foraminifera of the Jackson Eocene at Danville Landing on the Ouachita, Catahoula Parish, Louisiana. Bulletin Louisiana Department Geology, 2:18-79.

Hussein, A.I.M. 1994. Orbulinoides beckmanni zone (Biarritzian), a contribution to the stratigraphy of the Beni Suef Formation in the Nile Valley, Egypt. Revue de Paleobiology, 13(2):307-312.

Hussein, A.I.M. 1998. Middle Eocene palmate benthic foraminifera from the Nile Valley and their paleoecological significance. Ain Shams University Earth Science Series, Cairo, 12:214-218.

Hussein, A.W. 2019. Cyclic hierarchy and depositional sequences of the Middle-Upper Eocene ramp facies: An example from Beni Suef area, east Nile Valley, Egypt. Journal of African Earth Sciences, 149: 307-333. https://doi.org/10.1016/j.jafrearsci.2018.08.015

Imam, M.M. 1999. Lithostratigraphy and planktonic foraminiferal biostratigraphy of the Late Eocene-Middle Miocene sequence in the area between Wadi Al Zeitun and Wadi Al Rahib, Al Bardia area, northeast Libya. Journal of African Earth Sciences, 28:619-639. https://doi.org/ 10.1016/s0899-5362(99)00035-4

James, N.P. and Bone, Y. 2011. Carbonate production and deposition in a warm-temperate macroalgal environment, Investigator Strait, South Australia. Sedimentary Geology, 240:4153. https://doi.org/10.1016/j.sedgeo.2011.07.005

Jenkins, D.G. 1960. Planktonic foraminifera from the Lakes Entrance oil shaft, Victoria, Australia. Micropaleontology, 6:345-371.

Jenkins, D.G. 1966. Standard Cenozoic stratigraphical zonal scheme. Nature, 211:178.

Jenkins, D.G., and Orr, W. 1973. Planktonic foraminiferal biostratigraphy of the Eastern Equatorial Pacific -DSDP leg 9. Initial Reports of the Deep Sea Drilling Project, 9:1059-1193.

Karoui-Yaakoub, N., Grira, C., and Mtimet, M.S. 2017. Planktonic foraminiferal biostratigraphy, paleoecology and chronostratigraphy across the Eocene/Oligocene boundary in northern Tunisia. Journal of African Earth Science, 125:126-136. https://doi.org/10.1016/ j.jafrearsci.2016.11.009

Keijzer, F.G. 1945. Outline of the geology of the eastern of the Province of Oriente, Cuba (E of $76^{\circ} \mathrm{WL}$ ), with notes on the geology of other parts of the island. Geographsiche en Geologische Mededeelingen. Publicaties uit het Geographischen uit het Mineralogish Geologisch Instituut der Rijksuniversiteit te Utrecht. Physiographisch - GeologischeReeks, 6:1-239.

Keller, M.D., Selvin, R.C., Claus, W., and Guillard, R.R.L. 1987. Media for the culture of oceanic ultraphytoplankton. Journal of Phycology, 23:633-638.

Kenawy, A.I., Khalifa, H., and Mansour, H.H. 1977. Biostratigraphic zonation of the Middle Eocene in the Nile Valley, based on the larger foraminifera. Bulletin Faculty of Science Assiut University, Egypt, 6(2):237-259.

Koch, R.E. 1926. Mitteltertiare foraminiferen aus Bulongan, Ost. Borneo. Eclogae Geology Helv, 19(3):722-751.

Kooistra, W.H.C.F., Coppejans, E.G.G., and Payri, C. 2002. Molecular systematics, historical ecology, and phylogeography of Halimeda (Bryopsidales). Molecular Phylogenetics and Evolution, 24:121-138. https://doi.org/10.1016/s1055-7903(02)00221-x

Król, J.J., Kołodziej, B., and Bucur, I.I. 2017. Coral reefs near the Eocene-Oligocene boundary in the northern Transylvanian Basin, Romania: Composition and paleoenvironmental interpretation. Geological Journal, 53:1-15. https://doi.org/10.1002/gj.2913

Leckie, R.M. 1987. Paleoecology of mid-Cretaceous planktonic foraminifera: a comparison of open ocean and epicontinental sea assemblages. Micropaleontology, 33:164-176. https:// doi.org/10.2307/1485491

Leckie, R.M., Yuretich, R.F., West, O.L.O., Finkelstein, D., and Schmidt, M. 1998.

Paleoceanography of the southwestern Western Interior Sea during the time of the Cenomanian-Turonian boundary (Late Cretaceous), p. 101-126. In Dean, W.E. and Arthur, M.A. (eds.), Stratigraphy and Paleoenvironments of the Cretaceous Western Interior Seaway, U.S.A. SEPM Concepts in Sedimentology and Paleontology 6. https://doi.org/10.2110/csp.98.06.0101

Mansour, H.H., Philobbos, E.R., and Abdu, F.H. 1982. Contribution to the geology of the east and northeast of Beni Suef, Nile Valley, Egypt. Qatar University Science Bulletin, 11(8):52-65.

Marzouk, A.M., El Shishtawy, A.M., and Kasem, A.M. 2014. Calcareous nannofossil and planktonic foraminifera biostratigraphy through the Middle to Late Eocene transition of Fayum area, Western Desert, Egypt. Journal of African Earth Sciences, 100:303-323. https://doi.org/10.1016/j.jafrearsci.2014.07.003 
Morsilli, M., Bosellini, F.R., Pomar, L., Hallocks, P., Aurell, M., and Papazzoni, C.A. 2012. Mesophotic coral buildups in a prodelta setting (Late Eocene, southern Pyrenees, Spain): a mixed carbonate siliciclastic system. Sedimentology, 59:766-794. https://doi.org/10.1111/ j.1365-3091.2011.01275.x

Mukhopadhyay, S.K. 2003. A rare foraminiferal assemblage with new species of Nummulites and Globigerina from the Eocene-Oligocene transition strata of the Cambay Basin, India. Micropaleontology, 49:65-93. https://doi.org/10.1661/00262803(2003)049[0065:arfawn]2.0.co;2

Mukhopadhyay, S.K. 2005. Turborotalia cerroazulensis group in the Paleogene sequence of Cambay Basin, India with a note on the evolution of Turborotalia cunialensis (Toumarkine \& Bolli). Revue de Paléobiologie, 24(1):29-50.

Murray, J.W. and Alve, E. 1999. Natural dissolution of modern shallow water benthic foraminifera: taphonomic effects on the palaeoecological record. Palaeogeography, Palaeoclimatology, Palaeoecology, 146:195-209. https://doi.org/10.1016/s00310182(98)00132-1

Murray, J.W. 2006. Ecology and Applications of Benthic Foraminifera. Cambridge University Press, Cambridge.

Myatliuk, E.V. 1950. The stratigraphy of the flysch deposits of the northern Carpathian Mountains according to the foraminiferal faunas. Trudy VNIGRI, New Series, 51:225-287.

Nebelsick, J.H., Rasser, M., and Bassi, D. 2003. The development of facies patterns of Middle Eocene to Lower Oligocene circum-alpine shallow-water carbonate environments, p. 471491. In Prothero. D.R., Ivany, L.C., and Nesbitt, E.A. (eds.), From Greenhouse to Icehouse: The Marine Eocene-Oligocene Transition. Columbia University Press, New York.

Nebelsick, J.H., Rasser, M.W., and Bassi, D. 2005. Facies dynamics in Eocene to Oligocene circumalpine carbonates. Facies, 51:197-216. https://doi.org/10.1007/s10347-005-0069-2

Norris, R. D., Kroon, D., Klaus, A., Alexander, I.T., Bardot, L.P., Barker, C.E., Bellier, J.-P.,Blome, C., Clarke, L.J., Erbacher, J., Faul, K.L., Huber, B.T., Katz, M.E.,McLeod, K.G., Marca, S., Martinez-Ruiz, F.C., Mita, I., Nakai, M., Ogg, J.G., Pak, D.K., Pletsch, T.K., Self-Trail J.M.,Shackleton, N.J., Smit, J., William Ussler III, Watkins, D.K., Widmark, J. and Wilson, P.A. 1997. Proceedings of the Ocean Drilling Program. Scientific Results Leg 171B.

Obaidalla, N.A. and El Ayyat, A.M. 2001. Planktonic foraminiferal Orbulinoides beckmanni totaltange zone in the Nile Valley, Egypt. Bulletin Faculty of Science Assiut University, 30(1F):4351.

Palmer, D.K. 1934. The foraminiferal genus Gumbelina in the Tertiary of Cuba. Memoir Society Cubana Historical National, 8:73-76.

Pearson, P.N. and Chiasson, W.P. 1997. Paleocene to middle Miocene planktonic foraminifer biostratigraphy of the Ceara Rise. In Shackleton, N.J., Curry, W.B., Richter, C., and Bralower, T.J (eds.), Proceedings of the Ocean Drilling Program, Scientific Results, 154:33-68.

Pearson, P.N. and Wade, B.S. 2015. Systematic taxonomy of exceptionally well-preserved planktonic foraminifera from the Eocene/Oligocene boundary of Tanzania. Cushman Foundation Special Publication, 45:1-85.

Pearson, P.N., Shackleton, N. J., and Hall, M.A. 1993. Stable isotope paleoecology of Middle Eocene planktonic foraminifera and multi-species isotope stratigraphy, DSDP Site 523, South Atlantic. Journal of Foraminiferal Research, 23:123-140.

Pearson, P.N., Olsson, R.K., Huber, B.T., Hemleben, C., and Berggren, W.A. 2006. Atlas of Eocene Planktonic Foraminifera. Cushman Foundation Special Publication, 41.

Perrin, C. 2002. Tertiary: the emergence of modern reef ecosystems, p. 587-618. In Flügel, E., KiesslingW., and Golonka, J. (eds.), Phanerozoic Reef Patterns. SEPM Special Publication 72.

Peters, S.E., Antar, M.S., Zalmout, I.S., and Gingerich, P.D. 2009. Sequence stratigraphic control on reservation of Late Eocene whales and other vertebrates at Wadi Al-Hitan, Egypt. Palaios, 24:290-302. https://doi.org/10.2110/palo.2008.p08-080r

Pippèrr, M. and Reichenbacher, B. 2010. Foraminifera from the borehole Altdorf (SE Germany): Proxies for Ottnangian (early Miocene) palaeoenvironments of the Central Paratethys. Palaeogeography, Palaeoclimatology, Palaeoecology, 289:62-80. https://doi.org/10.1016/ j.palaeo.2010.02.009 
Pippèrr, M. 2011. Characterization of Ottnangian (middle Burdigalian) palaeoenvironments in the North Alpine Foreland Basin using benthic foraminifera-A review of the Upper Marine Molasse of southern Germany. Marine Micropaleontology, 79:80-99. https://doi.org/10.1016/ j.marmicro.2011.02.002

Postuma, J.A. 1971. Manual of Planktonic Foraminifera. Elsevier, Amsterdam.

Premoli Silva, I. and Bolli, H. M. 1973. Late Cretaceous to Eocene planktonic foraminifera and stratigraphy of Leg 15 sites in the Caribbean Sea. Initial Reports of the Deep Sea Drilling Project, 15:449-547.

Reuter, M., Piller, W.E., and Richoz, S. 2012. The dispersal of Halimeda in northern hemisphere mid-latitudes: palaeobiogeographical insights. Perspectives in Plant Ecology, Evolution and Systematics, 14:303-309. https://doi.org/10.1016/j.ppees.2012.03.003

Saber, S. G. and Salama, Y.F. 2017. Facies analysis and sequence stratigraphy of the Eocene successions, east Beni Suef area, eastern Desert, Egypt. Journal of African Earth Sciences, 135:173-185. https://doi.org/10.1016/j.jafrearsci.2017.09.006

Said, R. 1962. The Geology of Egypt. Elsevier, Amsterdam, New York.

Said, R., 1971. Explanatory notes to accompany the geological map of Egypt. 1:2.000.000. Geological Survey of Egypt, 56.

Sallam, E., Wanas, H.A., and Osman, R. 2015. Stratigraphy, facies analysis and sequence stratigraphy of the Eocene succession in the Shabrawet area (north Eastern Desert, Egypt): an example for a tectonically influenced inner ramp carbonate platform. Arab Journal of Geosciences, 8(12):10433-10458. https://doi.org/10.1007/s12517-015-1969-2

Samir, A.M. 1986. Stratigraphy of some Eocene sections in northern Egypt. Ph.D. Thesis, Faculty of Sciences, Alexandria University, Egypt.

Sarkar, S. 2016. Early Eocene calcareous algae and benthic foraminifera from Meghalaya, NE India: a new record of microfacies and palaeoenvironment. Journal of Geological Society of India, 88:281-294. https://doi.org/10.1007/s12594-016-0491-9

Scheibner, C., Kuss, J., and Marzouk, A.M. 2000. Slope sediments of a Paleocene ramp-tobasin transition in NE Egypt. International Journal of Earth Sciences, 88:708-724. https:// doi.org/10.1007/s005310050299

Selima, A.M.A. 1989. Some stratigraphical studies on the subsurface Eocene sections in the western reach of the Nile Valley between Beni Suef and Cairo. Unpublished Ph.D. Thesis, Faculty of Sciences, Ain Shams University.

Shahin, A. 1992. Contribution to the foraminiferal biostratigraphy and paleobathymetry of the Late Cretaceous and Early Tertiary in the western central Sinai, Egypt. Revue de Micropaleontgie, 16:79-154.

Shahin, A. 1998. Tertiary planktonic foraminiferal biostratigraphy and paleobathymetry at Gebel Withr, Southwestern Sinai, Egypt. Neues Jahrbuch für Geologie und Paläontologie, 209(3):323-348.

Smadi, A.A. 2002. Wadi Shallal Chalk Formation of east Jordan supplementary type section. 6th International Conference of Geology Arab World, Cairo University, 4:535-542.

Stainforth, R.M., Lamb, J.L., Luterbacher, H., Beard, J.H., and Jeffords, R.M. 1975. Cenozoic planktonic foraminiferal zonation and characteristics of index forms. University of Kansas Paleontological Contributions, 62:1-162.

Strougo, A. 1992. The Middle/Upper Eocene transition in Egypt reconsidered. Neues Jahrbuch für Geologie und Paläontologie, 186(1):71-89.

Strougo, A. 2008. The Mokattamian Stage: 125 years later. Publications of the Middle East Research Center, Ain Shams University, Earth Science Series, 22:47-108.

Strougo, A., Faris, M., Haggag, M., Abulnasr, R., and Gingerich, P. 2013. Planktonic foraminifera and calcareous nannofossil biostratigraphy through the Middle to Late Eocene transition at Wadi Hitan, Fayum Province. Contributions from the Museum of Paleontology, University of Michigan, 32(8):111-138.

Subbotina, N.N. 1947. Foraminifers of the Danian and Paleogene deposits of the northern Caucasus, p. 39-16. In Microfauna of the Caucasus Emba Region and Central Asia. Trudy VNIGRI, Leningrad.

Subbotina, N.N. 1953. Fossil foraminifera of the USSR: Globgrinidae, Hantkeninidae and Globorotalidae. Proceedings of the Oil Research Geological Institute (VNIGRI) Saint Petersburg, Russia. 
Tawfik, M., El-Sorogy, A.S., and Moussa, M. 2016. Metre-scale cyclicity in Middle Eocene platform carbonates in northern Egypt: implications for facies development and sequence stratigraphy. Journal of African Earth Sciences, 119:238-255. https://doi.org/10.1016/ j.jafrearsci.2016.04.006

Todd, R. 1957. Smaller foraminifera, p. 265-320. In Geology of Saipan Mariana Islands, Part 3, Paleontolology. U.S. Geological Survey Professional Paper, 280-E-J.

Toumarkine, M. and Bolli, H.M. 1970. Evolution de Globorotalia cerroazulensis (Cole) dans l'Eocéne moyen et supérieur de Possagno (Italie). Reveu de Micropaleontogie, 13:131-145.

Toumarkine, M. and Bolli, H.M. 1975. Foraminiféres planktoniques de l'Eocéne moyen et supérieur de la Coupe de Possagno. Schweizer Palaeontologie, 97:69-83

Toumarkine, M. and Luterbacher, H.P. 1985. Paleocene and Eocene planktonic foraminifera, p. 87-154. In Bolli, H.M., Saunders, J.B., Perc-Nielsen, K. (eds.), Plankton Stratigraphy. Cambridge University Press, Cambridge.

Vail, P.R., Michum, R.M., and Thompson, S. 1977. Seismic stratigraphy and global changes of sea level, part 4: global cycles of relative changes of sea level, p. 83-97. In Payton, C. (ed.), Seismic Stratigraphy-Applications to Hydrocarbon Exploration. American Association of Petroleum Geologists Memoir, 26.

Van der Zwaan, G.J., Jorissen, F.J., and De Stigter, H.C. 1990. The depth dependency of planktonic/benthonic foraminiferal ratios: constraints and applications. Marine Geology, 95:116. https://doi.org/10.1016/0025-3227(90)90016-d

Van Hinsbergen, D.J.J., Kouwenhoven, T.J., and Van der Zwaan, G.J. 2005. Paleobathymetry in the backstripping procedure: Correction for oxygenation effects on depth estimates. Palaeogeography, Palaeoclimatology, Palaeoecology, 221:245-265. https://doi.org/10.1016/ j.palaeo.2005.02.013

Viotti, C. and El Demerdash, G. 1969. Studies on Eocene sediments of Wadi Nukhul area, East Coast Gulf of Suez. Proceedings $3^{\text {rd }}$ African Micropaleontology Colloquium, Cairo, p. 403423.

Wade, B.S., Paul, N., Pearson, P.N., Berggren, W.A., and Pälike, H. 2011. Review and revision of Cenozoic tropical planktonic foraminiferal biostratigraphy and calibration to the geomagnetic polarity and astronomical time scale. Earth Science Review, 104:111-142. https://doi.org/10.1016/j.earscirev.2010.09.003

Wade, B.S. 2004. Planktonic foraminiferal biostratigraphy and mechanisms in the extinction of Morozovella in the late middle Eocene. Marine Micropaleontology, 51:23-38. https://doi.org/ 10.1016/j.marmicro.2003.09.001

Wanas, H.A., Sallam, E., Zobaa, M.K., and Li, X. 2015. Mid-Eocene alluvial-lacustrine succession at Gebel El-Goza El-Hamra (Shabrawet area, NE Eastern Desert, Egypt): facies analysis, sequence stratigraphy and paleoclimatic implications. Sedimentary Geology, 329:115-129. https://doi.org/10.1016/j.sedgeo.2015.09.006

Weinzierl, L.L. and Applin, E.R. 1929. The Caliborne Formation on the coastal domes. Journal of Paleontology, 3(4):384-410.

Woodroffe, C. D. and Webster, J.M. 2014. Coral reefs and sea-level change. Marine Geology, 352:248-267. https://doi.org/10.1016/j.margeo.2013.12.006

Zittel, K.A. 1883. Beitrage Zur Geologie und Palaontologie der libyschen Wuste und der angrenzenden Gebiete von Aegypten. Paleontographica, 30:1-12. 